Research Report No. 51/2009

\title{
Economic Analysis and Evaluation of "Fair Prices": Can Antitrust and International Taxation Learn from Each Other?
}

Alessandro Turina

Nicolo Zingales

Follow this and additional works at: http://digitalcommons.osgoode.yorku.ca/clpe

\section{Recommended Citation}

Turina, Alessandro and Zingales, Nicolo, "Economic Analysis and Evaluation of "Fair Prices": Can Antitrust and International Taxation Learn from Each Other?" (2009). Comparative Research in Law \& Political Economy. Research Paper No. 51/2009.

http://digitalcommons.osgoode.yorku.ca/clpe/159 


\section{Comparative Research in Law \& Political Economy}

CLPE RESEARCH PAPER 51/2009

Alessandro Turina \& Nicolo Zingales

Economic Analysis and Evaluation of "Fair Prices": Can Antitrust and International Taxation Learn from Each Other?

EDITORS: Peer Zumbansen (Osgoode Hall Law School, Toronto, Director, Comparative Research in Law and Political Economy, York University), John W. Cioffi (University of California at Riverside), Nassim Nasser (Osgoode Hall Law School, Toronto, Production Editor) 

CLPE Research Paper 51/2009

Vol. 05 No. 10 (2009)

\title{
Alessandro Turina \& Nicolo Zingales
}

\section{Economic Analysis and Evaluation of "FAir Prices": Can Antitrust AND INTERNATIONAL TAXATION LEARN FROM EACH OTHER?}

\begin{abstract}
The purpose of this paper is to illustrate the different kinds of concerns related to the notion of "unfair prices" in tax and competition policy, respectively. The focus is on the rules governing transfer pricing within the setting of international tax policy, and on those governing the treatment of excessive as well as predatory pricing, according to competition policy.

After a brief methodological background, the paper introduces the various notions of transfer, excessive and predatory pricing stressing the differences and similarities in the respective regulations. It does so distinguishing the rules established by the United States and the OECD, in the area of transfer pricing, and the different approach taken by the US and the EU, with respect to competition policy.

Finally, the paper advances some tentative reflections on the possible scope for convergence between the three aforementioned areas of enquiry, elaborating some proposals from a policy making perspective.
\end{abstract}

Keywords: Transfer Pricing, Predatory Pricing, Excessive Pricing, Economic Analysis of Law, Interdisciplinary Approach, Legal Certainty.

JEL classification: K21, K34

Alessandro Turina (alessandro.turina@taxworks.it),

Nicolo Zingales (nicolo.zingales@phd.unibocconi.it)

Ph.D. Candidates in International Economic Law, Bocconi University, Milan 


\title{
Economic Analysis and Evaluation of "Fair Prices": Can Antitrust and International Taxation Lean from Each Other?
}

\author{
Alessandro Turina \& Nicolo Zingales*
}

\section{INTRODUCTION}

Why should we be concerned about prices at all? According to the Chicago school of economics, markets ought to be left free from intervention simply because they will adjust themselves to the competitive price, and any form of intervention should be justified by analyzing the costs of action and proving the positive effects derived thereof ${ }^{1}$.

A first, simple theoretical answer is that markets are in reality far from the level of perfection assumed by the traditional Chicago school of thought.

A more practically concerned answer may be that pricing is one of the key issues in business economics, lying at crossroads between micro-economic theory and marketing strategies. Due to their lying directly at the core of any economic phenomenon, it should come as no surprise that prices are extremely sensitive variables also from an economic policy making perspective.

Prices, costs and profit margins are clearly interrelated, as, provided two of these basic data, the third can also be inferred. Based on this arithmetic evidence, it should first be made clear that when we speak about price analysis, we are also in a way speaking of costs and profit margins.

For public authorities, exerting any form of control or monitoring over any of such economic variables means touching the very heart of a market economy. As we have established why prices are so important from a public policy point of view, we may still wonder what areas of public policy intervention may directly impact on such economic indicators and on the grounds of which agenda.

The two areas of public economic policy that are more directly interested in such issues appear being tax policy and competition policy. Even though the purposes with which these two areas focus their attention on this dimension, as it will be outlined in the following sections, are different, it seems to us that there must be, or there should be, a common denominator between the two, at least from a methodological view point.

Typically, comparative law mostly adopts a territorially driven approach, that is, it tries to investigate how and why legal models circulate from one jurisdiction to another often leading to

\footnotetext{
* Alessandro Turina (alessandro.turina@taxworks.it), Nicolo Zingales (nicolo.zingales@phd.unibocconi.it), Ph.D. Candidates in International Economic Law, Bocconi University, Milan

${ }^{1}$ R.H. COASE, 'The Problem of Social Cost', in (1960) 3 Journal of Law and Economics, 1.
} 
cases of "legal transplants"2. Our "comparative" concern is different, as we would like to focus our enquiry on whether any form of cross-pollination can be foreseen between different areas of law and policy making, even within the boundaries of the same jurisdictions.

Generally, such dynamics are not unheard of and occur under the form of hierarchical cross references to legal concepts within a legal system, so that, for instance, when talking about tax law or competition law, we may not do without referring to concepts elaborated in private law, company law and international law. This kind of mechanism typically features a vertical dynamic, from the most general areas of law to the more specific ones. On the contrary, both tax law and competition law are very specialized fields of law; nonetheless, we still think that there might be some room for some degree of "horizontal" cross-pollination. Such cross-pollination basically revolves around a confrontation between the mechanisms adopted in different areas of law with respect to the handling of similar problems ${ }^{3}$.

It should come as no surprise that both tax law and competition law are the areas of law that probably rely to the greatest extent on economic concepts. In this context, what the law tries to accomplish is to "translate" economic concepts in a legal jargon, determining their implications and establishing legal hurdles that facilitate the judicial mastering of economic complexities.

The most obvious areas where tax law and competition law concepts and vocabulary intermingle is probably the topic of State Aid, to which the case law of the European Court of Justice has contributed to a wide extent. However, there are possibly other areas of public economic policy where tax and competition law are close to each other, at least from a methodological and procedural viewpoint: one of these areas is precisely what we broadly name "price-based analysis".

This paper, then, is first and foremost, a methodological enquiry whose aim is to illustrate the methods adopted by tax policy makers when dealing with the issue of transfer pricing and by competition law regulators and courts when confronted with the controversial issues of excessive pricing and predatory pricing.

Based on such an exposition, which is carried out respectively in the three central sections of this paper, a comparative analysis - in the peculiar sense we have exposed above - is attempted.

Such comparative analysis is carried out both by cross references in the individual sections of this paper as well as in the concluding remarks.

What emerges from this enquiry is that "price based analysis", either tax policy or competition policy driven, implies some compelling methodological questions that, at least in our view, are far from being settled and that, in summary terms, revolve around the fuzzy concept of "comparability".

\footnotetext{
${ }^{2}$ The expression "legal transplant", which has encountered long-lasting fortune in the realm of comparative law was originally elaborated in W.A.J. WATSON, Legal Transplants: An Approach to Comparative Law, Edinburgh, 2004.

${ }^{3}$ For a definition of the "triad" consisting of "models", "problems" and "mechanisms" in a tax setting see C. GARBARINO, An Evolutionary Approach to Comparative Taxation: Methods and Agenda for Research, 2009, 4. The paper can be accessed on the following website: http://papers.ssrn.com/sol3/papers.cfm?abstract_id=1116686.
} 
Furthermore, both areas of enquiry seem to have something to learn from each other from a procedural point of view with respect to general issues of legal certainty, per se legality, the allocation of the burden of proof and the dialectics between public authorities and private firms.

\section{SECTION 1: TRANSFER PRICING}

\section{A. THE ROLE OF MULTINATIONAL ENTERPRISES AND TRANSFER PRICING}

Within the context of a multinational group (hereinafter, M.N.E.), transfer prices are those prices that refer to intra-group transfers of goods, both tangible and intangible, and supplies of services. In the current globalised economic order, where M.N.E.s play a pivotal role, intragroup dealing account for more than $70 \%$ of cross-border world trade ${ }^{4}$.

Such a central role has made transfer pricing a subject of enquiry not only for business economics and tax policy analysts, but also for international economics, even though an assessment of this latter dimension falls outside of the scope of this paper.

It is generally understood that the adoption of transfer pricing legislation has historically been driven by the concern to prevent cross-border tax avoidance ${ }^{5}$, nonetheless the implications arising from transfer pricing issues are so pervasive that it can be pointed out that transfer pricing that lies at the heart of the international tax regime ${ }^{6}$.

It appears quite clearly that the basic mean by which residence-based taxation can be avoided is by shifting income from residents to non residents. The easiest way by which a M.N.E. can achieve this task is by manipulating transfer prices.

Namely, a M.N.E., at least at its more developed stage can be qualified as a multinational group of independent legal entities, incorporated under the laws of different States and typically having their tax residence in different States $^{7}$. At the same time, a multinational group represents a unitary economic entity.

From a tax perspective, it is then possible to pursue what could be defined as an arbitrage between the economic unitary dimension of a multinational group and its juridical atomization:

${ }^{4}$ P. KRUGMAN, M. OBSTFELD, International Economics. Theory and Policy, VIII Edition, Boston, 2008, 134.

${ }^{5}$ C. CHOE, C.E. HYDE, Multinational Transfer Pricing, Tax Arbitrage and the Arm's Length Principle, 2004, 1. This paper can be accessed on the following website: http://papers.ssrn.com/sol3/papers.cfm?abstract_id=600881.

${ }^{6}$ See R. AVI YONAH, International Tax as International Law. An Analysis of the International Tax Regime, Cambridge, 2007, 102. By "international tax regime" the Author intends a coherent set of rules, both treaty based and domestic which constitute a corpus reaching the status of customary international law, to the extent that Countries would not be free to adopt any international tax rules as they see fit, but rather operate within the boundaries of said international tax regime. Contra, see H.D. ROSENBLOOM, 'International Tax Arbitrage and the "International Tax System", (2000) 137 Tax L. Rev., 164.

${ }^{7}$ See D. VAGTS, 'The Multinational Enterprise: A New Challenge for Transnational Law', (1970) 4, Harv. L. Rev., 742 . 
on one hand, it is possible to shift income from one Country to another, taking care that profits accrue to lower tax jurisdictions while the matching expenses be borne by entities situated in higher tax jurisdictions; on the other hand, the unitary economic dimension of a multinational group allows for a consolidation of the tax benefits arising from the above described income shifting technique, without affecting the global economic performance of the group.

Assuming that there were some form of tax coordination or ex post revenue sharing between the Countries where the group subsidiaries are situated, the above described scheme would be neutral also to the Treasuries of the concerned Countries. As it is well known, this is however not the case, not even in otherwise relatively integrated regional organizations such as the European Union.

In the following Paragraphs, the key introductory issues in transfer pricing will be addressed with the attempt to provide a sound background for interdisciplinary discussion. At the same time, cross references to comparable issues to be found in the realm of competition law in relation to excessive pricing and predatory pricing analysis will be made when appropriate.

\section{B. HISTORICAL DEVELOPMENTS IN TRANSFER PRICING LEGISLATION}

The oldest form of national transfer pricing legislation is to be found in the United States and dates back in its archetypal form to World War I "War Revenue Act", even though key issues such as the definition of what should be considered as an arm's length benchmark was introduced only in the late 30 ' $\mathrm{s}^{9}$.

On the other hand, with the exception of some Anglo - Saxon Countries ${ }^{10}$, most tax jurisdictions did not encompass specific transfer pricing rules.

Nonetheless, the fundamental conceptual tool to transfer pricing, the arm's length principle has been embedded since 1963 in the OECD Model Convention under Art. 9 and has thus encountered a wide circulation in the majority of double taxation treaty networks.

In 1979, the OECD assumed the task to provide guidance with respect to the application and interpretation of the arm's length principle, thus setting forth a common standard in transfer pricing matters encapsulated in the OECD Transfer Pricing Guidelines for Multinational Enterprises and Tax Administrations. The 1979 version of the OECD Guidelines has ever since been updated in 1995, 2000 and, most recently, in 2009.

As it will be outlined further on in this paper, despite the globalised nature of transfer pricing, which much owes to the balanced compromise represented by the OECD Transfer Pricing Guidelines, a tension clearly exists between the US approach to the subject, more thoroughly developed and which attributes a greater role to profit - based outlooks ${ }^{11}$ and what could be defined as the Continental approach to transfer pricing, represented in particular by the

\footnotetext{
${ }^{8} 1917$ War Revenue Act, Regulation 41, Art. 77 -78.

91935 Treasury Regulations, Section $45-1$.

${ }^{10}$ Most notably, the United Kingdom and Canada.

${ }^{11}$ In particular, the Comparable Profits Method, introduced with the 1994 Regulations.
} 
German and the Swedish legislation, more faithful to the original transaction based methods of the 1979 OECD Transfer Pricing Guidelines.

\section{Methods to DETERMINE THE ARM’S LENGTH PRICE}

\section{HISTORICAL RECONSTRUCTION OF THE APPLICATION OF THE ARM’S LENGTH STANDARD}

The first appearance of the expression "dealing at arm's length" in international tax policy circles is not clear.

The most consolidated historical reconstruction ${ }^{12}$ in this respect suggests that the use of this expression has its roots in the United States, with the first formal reference in the US Treasury Regulations of 1935.

From a purely legal history perspective, the entry of what could have remained an isolated national tax concept into the international tax koine can only be understood by making reference to a Survey concerning the issue of the taxation of foreign and national enterprises drafted by the Fiscal Committee of the League of Nations under the chairmanship of Mitchell B. Carroll. The report also included a seminal reference to the emerging issue of transfer pricing, as it called for "an enquiry into the relations between the local branch and other establishments of the parent enterprise, which involve (...) consideration of the price at which goods have been invoiced and the amounts charged for services (...) or representing a portion of general overhead expenses" $"$.

When the Fiscal Committee was asked to draft a model multilateral treaty concerning the issue of the allocation of business profits, the 1933 Multilateral Model, a forerunner to the current version of Art. 9 of the OECD Model was included, foreseeing the possibility that Tax Authorities may make adjustments in situations where related enterprises practiced conditions different from those which would have been made by independent enterprises.

Ever since, through the mediation of further model conventions drafted by the Fiscal Committee of the League of Nations, of which the last version, agreed upon during a London round of meetings in 1946, came to be known as the "London Model", the idea that the cross border transactions between related enterprises had to be monitored and subject to enquiry passed right into the 1963 OECD Model Convention with the formulation of Art. $9^{14}$.

\footnotetext{
${ }^{12}$ See, in particular, H. HAMAEKERS, ‘Arm's Length - How Long?', (2001) 3, I.T.P.J., 32.

${ }^{13}$ M.B. CARROLL et Al., Taxation of Foreign and National Enterprises, Volume IV , Geneva, 1933, 132, reported by H. HAMAEKERS, supra note, 31

${ }^{14}$ The 1963 version of Art. 9 of the OECD Model Convention read as follows: "Where a) an enterprise of a Contracting State participates directly or indirectly in the management, control or capital of an enterprise of the other Contracting State, or b) the same persons participate directly or indirectly in the management, control or capital of an enterprise of a Contracting State and an enterprise of the other Contracting State, and in either case conditions are made or imposed between the two enterprises in their commercial or financial relations which differ from those which would be made between independent enterprises, then any profits which would, but for those
} 
The root of the arm's length principle is then grounded in a specific provision of the OECD Model Convention as well as in the analogous provision of the UN Model.

Nonetheless, the enunciation of the arm's length principle was set forth in such broad terms that a general consensus emerged at an OECD level for the drafting of more detailed guidelines outlining the concrete application of the arm's length principle.

\section{FROM ONE STANDARD TO FIVE (AND MORE) METHODS}

\subsection{Transaction based methods}

In 1979, the Committee on Fiscal Affairs and the Council of Ministers of the OECD adopted a Report (hereinafter, the 1979 Report) which provided guidelines to tax administrations and M.N.E.s on the concrete implementation of the arm's length principle.

The 1979 Report recommended three transfer pricing methods:

method) ${ }^{15}$;

the "comparable uncontrolled price" method (hereinafter, C.U.P.

- the "cost plus" method ${ }^{16}$;

- the "resale price" method".

These methods are generally defined under the umbrella term "transaction based methods".

The C.U.P. method is based on a comparison between the comparable controlled transaction, that is the infra-group transaction which is under scrutiny and the comparable uncontrolled transaction which may have taken place either between an entity included in the multinational group and a third party or between third parties unaffiliated with the multinational group.

Comparability requires that no difference in the compared transactions nor between the enterprises that carry out said transactions be such to influence the arm's length price. If this is not the case, such difference may be eliminated by resorting to the appropriate adjustments.

It is widely recognized that the C.U.P. method faces particular implementation difficulties as it is not always easy to find adequately comparable transactions. In these cases, it is possible to resort to the other two transaction-based methods, such as the resale price and cost plus method.

conditions, have accrued to one of the enterprises, but, by reason of those conditions, have not so accrued, may be included in the profits of that enterprise and taxed accordingly."

${ }^{15}$ Currently disciplined by Para. $2.18-2.24$ in the 2009 version of the OECD Transfer Pricing Guidelines for Multinational Enterprises and Tax Administrations (hereinafter, OECD Transfer Pricing Guidelines).

${ }^{16}$ Currently disciplined by Para. $2.25-2.42$ of the 2009 version of the OECD Transfer Pricing Guidelines

${ }^{17}$ Currently disciplined by Para. $2.43-2.59$ of the 2009 version of the OECD Transfer Pricing Guidelines 
The "resale price" method is based on the assumption that the arm's length price equals the resale price at which a product that has been bought by a related seller is sold to an unrelated party minus a profit margin. Said profit margin should be such to offset the operating expenses borne by the reseller - on the grounds of the kind of activity and of the functions carried out, of the assets deployed and of the risks undertaken - and to incorporate an adequate share of profits for the reseller.

The "cost plus" method is based on the assumption that the arm's length price equals the cost of production augmented by a profit margin determined by multiplying the production costs by a given markup. Such mark up encompasses the value of the functions to be fulfilled by the parties and the size of the risk to be borne, including, for example, guarantees, market risk, foreign exchange risk and is related to the value of the functions to be fulfilled. The mark up should be determined by operating a comparison with comparable transactions conducted by the group entities with third parties or between third parties external to the group.

The cost plus method is typically applied with reference to infra-group transactions revolving around semi-manufactured products that undergo an easily apportionable addition of value through the production pipeline.

It has been remarked that the "cost plus method" is the transaction based method which more apparently departs from the general and traditional understanding of the arm's length standard in a purely transaction based setting, to the extent that it may be considered much closer to one of the profit based methods ${ }^{18}$ that will be outlined in the following paragraphs.

The same conclusion may be extended also to the "resale price" method, as it seems quite intuitive to see a close connection between the cost plus method and the resale price method, to the extent the two appear almost being reversed variants of the very same conceptual approach ${ }^{19}$. Such a circumstance would seem to validate the thesis according to which the distinction between transaction based and profit based methods is a conventional one, as a continuum where different methods fade into each other - from strictly transaction based C.U.P. to profit split methods - can be envisaged, rather than a juxtaposition ${ }^{20}$.

The 1979 Report did not exclude the application of other methods ${ }^{21}$, such as the profit split method. At the same time, the 1979 Report clearly stated that implementation approaches

\footnotetext{
${ }^{18}$ A. CASLEY, 'The Basic Framework of the Cost Plus Method', (1999) 3 I.T.P.J., 44

${ }^{19}$ See R. AVI YONAH, supra note 6, 105

${ }^{20}$ In this sense, R. AVI YONAH, The Rise and Fall of Arm's Length. A Study in the evolution of U.S. International Taxation, 2006, University of Michigan Law \& Economics, Olin Working Paper, No. 07 - 017, 2. The paper can be accessed on the following website: http://papers.ssrn.com/sol3/papers.cfm?abstract id=1017524. The Author states that such continuum also includes formulary methods at one of the extreme opposite ends. This view is however generally disputed, to the extent that the OECD Transfer Pricing Guidelines openly characterize formulary apportionment as a non arm's length method. In this respect, since this section of this paper focuses in particular of an exposition of the arm's length standard in order to set the background for debate between a tax law perspective on the subject and a competition law one, formulary apportionment will not be addressed. For a thorough and sympathetic contribution concerning the fundamentals of this methodology see, ex multis, W. HELLERSTEIN, 'The Case for Formulary Apportionment', (2005) 5 I.T.P.J., 103.

${ }^{21}$ This openness applies also to later versions of the OECD Transfer Pricing Guidelines.
} 
based on the comparison of net profits could not be considered applicable outside of a general prima facie screening method for tax administrations ${ }^{22}$.

All the three aforementioned transaction - based transfer pricing methods that had been incorporated in the OECD 1979 Report were earlier developed in the United States. The original reference was to be found in the 1968 Regulations referring to Section 482 of the Internal Revenue Code (hereinafter, IRC) and originally focused on the transfer of tangible property, even though the concrete implementation of such methods was progressively shaped in the following decade.

\subsection{The rise of profit based methods}

Over the years, capitalizing on the creative outcomes of case law, alternative approaches to the actual implementation of the arm's length principle led to a flourishing of alternative methodological proposals ${ }^{23}$.

Moreover, the amendment of Sec. 482 of the "Internal Revenue Code" (hereinafter, I.R.C.) set forth by the 1986 US Tax Reform also promoted a discussion on new transfer pricing methods. In particular, in 1988, the idea that new methods centered on the comparison of operating profits was set forth in a "White Paper" 24 where a "basic arm's length return" method (hereinafter, B.A.R.L.M.) was outlined and whose application was advocated with respect to transactions involving the transfer of intangibles. B.A.R.L.M. basically consisted in determining an appropriate return for the use of an intangible transferred within a multinational enterprise by applying industry-wide return rates to the assets and functions performed by the parties to the actual transactions ${ }^{25}$.

It has been remarked that the "White Paper" represented an apparent downturn of the application of traditional comparability methods as, in many instances, the traditional transaction based methods had proven to be inapplicable, as no comparables could be found ${ }^{26}$. The seminal proposals contained in the "White Paper" were then instrumental in promoting an "expanded definition of the arm's length standard" ${ }^{27}$. In particular, instead of embracing a theoretical top down approach, often detached from the practical problems arising from a narrow and dogmatic take on the arm's length principle, a bottom up perspective was adopted: a transfer pricing continuum was somewhat defined, starting from the traditional and often unworkable C.U.P. to

\footnotetext{
${ }^{22}$ See in particular Para. 71 of the 1979 OECD Report

${ }^{23}$ For an overview, see H.D. ROSENBLOOM, 'The U.S. Approach to Transfer Pricing: Benchmarks and Hallmarks', (2006) 2 Fiscalità Internazionale, 135

${ }^{24}$ I.R.S. Notice $88-123,1988-2$ C.B. 458,475

${ }^{25}$ For an overview of B.A.L.R.M., see D. FRISCH, 'The BALRM Approach of Transfer Pricing', (1989) 3 Nat'l Tax $J ., 261$

${ }^{26}$ See R. KAPLAN, 'International Tax Enforcement and the Special Challenge of Transfer Pricing', (1990) $319 U$. Ill. L. Rev., 299.

${ }^{27}$ R. AVI YONAH, supra note $20,14$.
} 
profit split methods; any take on this ideal thread could be considered acceptable as long as the deriving outcome was compatible with arm's length results ${ }^{28}$.

The 1988 "White Paper" eventually evolved into a formal amendments to the existing regulations in 1994. The amended Regulations concerning Section 482 of the IRC covered the whole transfer pricing matter and saw the introduction of two new formalized methods:

- the comparable profits method;

- the profit split method.

The comparable profits method (hereinafter, C.P.M.) was centered on the assessment of the operating profit that the tested party would have earned from intra-group transactions if its profit level indicators (most typically, the E.B.I.T., "Earnings Before Interest and Taxes") were equal to those realized by an uncontrolled comparable party ${ }^{29}$. The main detachment from the traditional transaction based methods consisted in the circumstance that the considered profit level indicators are those referred to the controlled taxpayer's more narrowly identifiable business activity encompassing the controlled transactions. As a consequence, an arm's length range may be defined if more than one reliable arm's length result become available ${ }^{30}$.

In particular, with respect to the application of the C.P.M., an arm's range is defined in the interval between the $25^{\text {th }}$ and the $75^{\text {th }}$ percentile, outside of which, the IRS is entitled to apply adjustments. This approach has been subject to some criticism due to the fact that it is very sensitive to the managerial accounting policies adopted by the company. Nonetheless, its flexibility and the fact that it can be applied without embarking on complex property and services comparability analysis or functional analysis; this has made the C.P.M. the preferred method adopted by the IRS. At the same time, at a scholarly level, the C.P.M. has been subject to both criticism and praise. In particular, it has been held that C.P.M. tends to lead to a form of presumptive taxation $^{31}$. On the other hand, C.P.M. has also been praised for its "hands on" approach to transfer pricing and its suitability for being applied to modern business ${ }^{32}$.

It has also been remarked that asserting that the C.P.M. is at irreconcilable variance with the arm's length principle may not be sustainable, since the different transfer pricing methods represent different spots on a continuum which goes from C.U.P. and its strictly transactional approach to the C.P.M. that, if one hand falls outside the traditional notions of arm's length under some respects, it still incorporates some elements of comparability analysis, which is probably the real core concern of any arm's length transfer pricing reasoning. The fact that C.P.M. is based on aggregated profits rather than transactions should not be seen as an exception, since, as it has been already exposed, also traditional methods such as the "cost plus" and the "resale price" method refer, in the definitive, to profit level indicators ${ }^{33}$.

\footnotetext{
${ }^{28}$ In this sense, D. FRISCH, 'Comments on the Proposed US Regulations on Transfer Pricing from an Economic Perspective', (1992) 3 Intertax, 340.

${ }^{29}$ H. HAMAEKERS, 'The Comparable Profits Method and the Arm's Length Principle', (2003) 5 I.T.P.J., 90.

${ }^{30}$ D. OOSTERHOFF, J. P. DONGA, 'Practical Application of Transactional Profits Methods', (2001) 1 I.T.P.J., 5.

${ }^{31}$ In this sense, H. HAMAEKERS, supra note $29,91$.

${ }^{32}$ In this sense, R. AVI YONAH, supra note 6, 117.

${ }^{33}$ D. OOSTERHOFF, J. P. DONGA, supra note $30,1$.
} 
On the other hand, the profit split method departed even more significantly from the traditional arm's length methods as it implied for a two step process. The first phase consists in an assessment of the functions performed by each of the related parties and the subsequent allocation of a market rate of return allocated to each function on the basis of comparables. A second phase transcends the very notion of comparability, as the residual profit is eventually split between the related parties on the grounds of a formula. In this respect, it appears quite clearly that the profit split method also incorporates a formulary apportionment component, even though no specific formula is used.

A few months after the new 1994 US Regulations were adopted, the OECD responded with the finalization of a new set of Transfer Pricing Guidelines in 1995. The 1995 OECD Transfer Pricing Guidelines represented a compromise, as they tried to render the C.P.M. developed in the United States more acceptable also to European Countries (in particular, Germany and Sweden) that were rather skeptical about it, due to the fact that they thought that C.P.M. conflicted with the arm's length principle encapsulated in Art. 9 of the OECD Model Convention $^{34}$. In this respect, it would seem that the OECD was not very successful, as, even nowadays, Germany does not fully endorse profit - based transfer pricing methods ${ }^{35}$.

In particular, the OECD set forth a partial alternative to C.P.M. going under the name of "Transactional Net Margin" method (hereinafter, T.N.M.M.). Like C.P.M., the T.N.M.M. is based on a comparison of operating profits, even though T.N.M.M. should be applied transaction by transaction rather than at an aggregated level ${ }^{36}$.

From an implementation viewpoint, the profit level indicator more commonly adopted are the E.B.I.T. on sales, E.B.I.T. on total costs or E.B.I.T. on total assets (also known as the "R.O.A." - return on assets - ratio).

As in other transfer pricing methodologies, comparability plays a key role. Namely, the net margin realized by group entities with respect to specific infra-group transactions should be compared with the net margins realized by entities dealing at arm's length. In this respect, tracking down different transactions by macro-categories and defining the actual content of the transaction (e.g., pure sale vs. sale and provision of some additional services) is a key factor in the actual implementation of the T.N.M.M..

The earlier mentioned focus on transactions is quite understandable bearing in mind the historical development of the arm's length principle; at the same time, such a concern seems to be an attempt to reconcile the non-reconcilable. The very expression "transfer pricing methods" which, before anything else, are actually pricing criteria that M.N.E.s should follow when setting prices, the perspective is thus ex ante. Profits based methods, on the contrary, are by their very nature based on ex post considerations, as these methods are not suitable to settle prices in advance but, rather, serve as a sanity check when analyzing or checking out the outcomes of transactions, which may then be considered at an aggregate level. How to combine profit based

\footnotetext{
${ }^{34}$ H. HAMAEKERS, supra note 12,31 .

${ }^{35}$ ERNST \& YOUNG, Global Transfer Pricing Survey, 2009. The survey can be accessed on the following website: http:/www.ey.com/GL/en/Services/Tax/2009-Global-Transfer-Pricing-survey.

${ }^{36}$ For an in depth comparative analysis of C.P.M. and T.N.M.M., see A.CASLEY, A. KRITIKIDES, 'Transactional Net Margin Method, Comparable Profits Methods and the Arm's Length Principle', (2003) 9 I.T.P.J., 162.
} 
methods with a focus on transactions, as advocated by the OECD Transfer Pricing Guidelines, appears then to be a conundrum ${ }^{37}$.

\section{THE ISSUE OF COMPARABILITY: AN ENLARGED PERSPECTIVE}

In the definitive, apart from the C.U.P. method, all transfer pricing methods seem to rely on the comparison between profit margins realized in infra-group transactions with profit margins realized between parties dealing at arm's length.

In this respect, transfer pricing is a conceptual tool mostly revolving around comparing economic indicators, in this respect the issue of comparability assumes a key place in the whole transfer pricing conceptual framework.

It should be remarked that the issue of comparability is one of the items which are common both to the transfer pricing for tax agenda and the excessive pricing and predatory pricing agenda falling into the purview of competition law.

Comparability appears as a logical process having an eminently economic content whose purpose is to ensure that the economically relevant characteristics of the situations being compared be adequately comparable, whereas being comparable means that none of the possible differences between the situations being compared could materially affect the condition being examined in the light of a given transfer pricing methodology.

In direct connection to the comparability analysis we find the adjustments that allow an actual comparability between the transactions under scrutiny and those assumed as a term of comparison in a sort of "comparative statics" approach.

In this respect, the OECD Transfer Pricing Guidelines recommend that when establishing whether there is comparability between the situations being compared and the adjustments deemed as necessary, Tax Authorities should take into account a number of variables representing the foreseeable economic differences that may require the adoption of adjustments.

Depending which transfer pricing methodology is adopted the comparability analysis can assume as its point of reference either prices or profit margins.

On any account, the OECD Transfer Pricing Guidelines do not endorse a purely stylized statistical approach to the issue of comparability, as it has on the contrary been also set forth in literature ${ }^{38}$. Namely, a purely statistically based approach to the issue of comparability would leave no room for the carrying out of qualitative case - by - case adjustments ${ }^{39}$, as it is on the contrary recommended by the very OECD Transfer Pricing Guidelines, since, "in no event can unadjusted industry average returns themselves establish arm's length conditions" ${ }^{40}$.

\footnotetext{
${ }^{37}$ See P. FRIS, 'Dealing with Arm's Length and Comparability in the Years 2000', (2003) 11 I.T.P.J., 195.

${ }^{38}$ See J. VAN DER MEER - KOOISTRA, ‘A Model for Making Qualitative Transfer Pricing Adjustments', (2004) 9 I.T.P.J., 190.

${ }^{39}$ P. FRIS, supra note $37,202$.

${ }^{40}$ See Para. 1.162009 OECD Transfer Pricing Guidelines.
} 
The key variables to be examined within the context of a comparability analysis can thus be summarized as follows:

- the characteristics of property or services ${ }^{41}$;

- functional analysis ${ }^{42}$;

- $\quad$ contractual terms ${ }^{43}$;

- $\quad$ economic circumstances ${ }^{44}$; and

- business strategies ${ }^{45}$.

While a thorough analysis of all the aforementioned different dimensions constituting part to the comparability analysis would go beyond the scope of this paper, we would like to focus on two of the aforementioned aspects, due to their proximity to similar problems encountered in the domain of competition law with respect to the matters of excessive pricing and predatory pricing.

Comparability analysis necessarily takes into account how markets affect the infra-group transactions under scrutiny. In this respect, it is required that the markets in which the independent and associated enterprises operate are comparable and that the differences do not have a material effect on price ${ }^{46}$.

In order to conduct an assessment of the market conditions for comparability analysis purposes, it is first of all necessary to identify the relevant market taking into account merceological characterizations. Further elements to be ascertained include the geographical location $^{47}$, the economic cycles ${ }^{48}$, the size of the market, the competitive forces operating in the market and the actual relative competitive positions occupied in such markets by the buyers and the sellers. Further elements to be taken into account in the market segmentation are the endogenous and exogenous forces that shape such markets, as, for instance, the purchasing powers of the consumers, the degree of regulation of the market, the different stages of the commercialization pipeline (e.g., wholesale Vs. retail) ${ }^{49}$.

Another key element to be taken into account and that is particularly relevant for the purposes of our joint enquiry is how costs of production and commercialization (including, for instance, transportation costs) are taken into account.

\footnotetext{
${ }^{41}$ This issue is covered by Para. 1.19 of the 2009 OECD Transfer Pricing Guidelines.

42 This issue is covered by Paras. $1.20-1.27$ of the 2009 OECD Transfer Pricing Guidelines.

${ }^{43}$ This issue is covered by Paras. 1.28 -129 of the 2009 OECD Transfer Pricing Guidelines.

44 This issue is covered by Para. 1.30 of the OECD Transfer Pricing Guidelines.

${ }^{45}$ This issue is covered by Para. 1.31 of the OECD Transfer Pricing Guidelines.

${ }^{46}$ In such cases, the adequate adjustments should be performed.

${ }^{47}$ In this respect, the 2009 version of the OECD Transfer Pricing Guidelines openly admit the use of a multiplecountry comparability analysis.

${ }^{48}$ Reference to this variable has been added only in the 2009 OECD Transfer Pricing Guidelines at Para. 1.55.

${ }^{49}$ These latter elements were introduced by the 2000 version of the OECD Transfer Pricing Guidelines.
} 
A second aspect of comparability analysis, which acquires greater relevance from a joint tax law and competition law perspective is the ascertainment of how business strategies are factored in when conducting a comparability analysis for transfer pricing purposes.

In this respect, it may result beneficial to make reference to the underlying microeconomic background to the matter, that is, how companies are expected to determine inter-company prices regardless of exogenous legal constraints.

Standard economic theory tells us that such transactions should be conducted at marginal cost: such a marginal cost rule will eliminate any inefficiencies arising from double marginalization. ${ }^{50}$. On the other hand, for multinational firms with affiliates operating in different tax jurisdictions, transfer prices serve more than tracking internal transactions for managerial accounting purpose, as they also determine tax liability of affiliates in different countries, hence the overall tax liability of the multinational enterprise.

The OECD Transfer Pricing Guidelines on this point do not seem to be very open to welcome insights from microeconomic pricing theory; on the contrary, the US 1988 "White Paper" contained a short chapter on economic theories concerning the implementation of Section 482 of the IRC where it adopts a reversed approach, stating that arm's length transactions could be reconstructed by looking at the arrangements unrelated parties would have made if they could choose to have the costs of related parties ${ }^{51}$.

One of the few purely microeconomic aspects the OECD Transfer Pricing Guidelines openly take into account, although from a business strategy perspective, is the issue of market penetration pricing strategies, as reference is made to a situation where an M.N.E. is in such a position to be willing to penetrate a market or to increase its market share by temporarily charging a price for its products which is lower than the price for otherwise comparable products in the same market. Similarly, it is recognized that a taxpayer seeking to enter a new market may incur in start - up costs that may temporarily hinder its profitability. In this respect, Tax Administrations are asked to evaluate whether such business strategies are actually being implemented or are used only as a cover up and whether the adopted strategy can be plausibly expected to be profitable in the future and that parties at arm's length would have been prepared to sacrifice pro tempore profitability in order to better deal with the competitive structure of the markets. According to the OECD Transfer Pricing Guidelines it is also relevant to ascertain whether the nature of the relationship between the parties to the controlled transaction would be consistent with the taxpayer bearing the cost of the business strategy.

Another interesting issue to be examined from an interdisciplinary perspective is the use of adjustments in order to neutralize the effects of possible government intervention policies. According to the OECD Transfer Pricing Guidelines, among such forms of government intervention policies we also find forms of price controls.

Whether competition law - backed forms of price assessment such as excessive pricing or predatory pricing monitoring are also to be accounted among the government intervention policies to be factored in when implementing comparability adjustments for transfer pricing purposes is an issue that seems to have been ignored so far both in literature and in guidelines.

\footnotetext{
${ }^{50}$ See J. HIRSHLEIFER, 'On the Economics of Transfer Pricing', (1956) 9 Journal of Business, 178.

${ }^{51}$ Reported by R. AVI YONAH, supra note 20, 26.
} 
There is no doubt that, in general terms, all forms of government interventions should be accounted for among other "conditions of the market" of a given Country or set of Countries. If such conclusion is quite apparent for forms of direct government intervention, such as actual price controls, on the other hand, the same kind of effects could derive in the long run from ex ante economic policy regulations, to which many competition law provisions can be ascribed.

The OECD Transfer Pricing Guidelines set forth that in order to conduct a suitable comparability analysis for transfer pricing purposes it is necessary to ascertain the stage at which price controls affects the price of the products sold by the company or of the services supplied and whether the impact of such policies impact only on the final consumer or also on other actors on the supply chain.

While "hard constraints" deriving from price controls can be easily isolated, the constraints deriving from indirect forms of control embodied, for instance, by the European excessive pricing rules, are very difficult to quantify but it would not be inconsistent with the general framework of comparability analysis to hold the view that they should be weighted in.

\section{E. DRIVERS BEHIND THE CHOICE OF A TRANSFER PRICING METHOD}

The 1995 OECD Transfer Pricing Guidelines departed from their US counterpart on a key issue, the hierarchy or - more aptly said - the criterion of choice for endorsing a methodology over another.

Namely, the 1994 US Transfer Pricing Regulations established the admissibility of all the five above described methods and, at the same time, saw the introduction of the so-called "best method" rule, according to which the method that should be eventually endorsed is the one which best approximates the arm's length price and imports the fewest adjustments to the comparables $^{52}$.

Thus, in the choice of the best method, two key criteria have to be factored in:

- the comparability with the free market situation;

- the quality of the gathered data as well as of the underlying assumptions.

On the other hand, the 1995 OECD Guidelines adopted an approach which was at once more liberal and vaguer, as they did not provide, in practice, and effective criterion for sorting out different methods and for defining a hierarchy among them so to pre-emptively settle disputes between tax administration holding different views on which method is preferable.

At the same time, it seems to us that the US "best method" approach is also not thoroughly endorsable. It may be true that a questionable criterion is better than no criterion at all, but the "best method" approach seems to carry along some remarkable pitfalls, which can summarized in the simple observation that such rule implies the tentative pre-emptive investigation of all of the specified methods ${ }^{53}$.

\footnotetext{
${ }^{52}$ R. AVI YONAH, supra note $6,114$.

${ }^{53}$ H. HAMAEKERS, supra note 29, 92.
} 
On the other hand, the OECD has indeed established a ranking of preferences, constantly affirming over the different versions of its transfer pricing Guidelines that the arm's length is central to the transfer pricing system and that formulary approaches such as formulary apportionment would then be at variance with the principles governing international taxation, of which the arm's length standard is a key criterion ${ }^{54}$.

Within the context of the codified methods it was also still possible to derive a preference given by the Fiscal Affairs Committee to transaction based methods as opposed to profit based methods ${ }^{55}$.

Nonetheless, such ranking appears to be of scarce practical relevance, as in some cases M.N.E.s do not really have a choice in finding the applicable transfer pricing methodology. In some cases, transactional methods may be applicable but much more burdensome to fine tune than their profit based counterparts. In this case, the hierarchy set forth by the OECD Guidelines would be of no help but may rather create further difficulties for M.N.E.s.

The issue of the hierarchy between different transfer pricing methods has encountered a remarkable deviation following to the update of the OECD Transfer Pricing Guidelines which took place in 2009. In particular, the exceptionality associated with the transactional profit based methods has been overcome and a new functional standard has been set forth, according to which, the selected transfer pricing method should be the most appropriate method to the circumstances of the case. How such a qualification interacts with the best profit method adopted in the US is a matter that will likely rise the attention of future commentators.

Nonetheless, the 2009 OECD Transfer Pricing Guidelines clearly state that M.N.E.s cannot be expected to apply more than one transfer pricing methodology and this would seem to exclude the need to counterproof the results obtained under the method of choice with other possible alternative applicable methods in order to ascertain whether the adopted method is the "best method". Namely, the Guidelines clarify that while in some cases the selection of a method may not be straightforward and more than one method may be initially considered, it will be possible to select one method that is apt to provide the best estimation of an arm's length price ${ }^{56}$.

The new OECD Transfer Pricing Guidelines generally state that "the respective strengths and weaknesses of each of the OECD recognised method should be taken into account" particular, the new OECD Transfer Pricing Guidelines further suggest the appropriateness of the method considered should be valued in the light of the following:

- the nature of the controlled transaction, determined in particular through a functional analysis;

- the availability of reasonably reliable information (in particular on uncontrolled comparables);

- the degree of comparability of controlled and uncontrolled transactions (and the reliability of the comparability adjustments that may be needed to eliminate differences between them).

\footnotetext{
${ }^{54}$ In this sense, J. OWENS, 'Should the Arm's Length Principle Retire?', (2005) 5 I.T.P.J., 103.

${ }^{55}$ Reference should be made, in particular, to Para. 1.14 of the 1996 OECD Transfer Pricing Guidelines.

${ }^{56}$ See Para. 2.10 of the 2009 OECD Transfer Pricing Guidelines.

${ }^{57}$ See Para. 2.1 of the 2009 OECD Transfer Pricing Guidelines.
} 
The most apparent outcome of such an approach is that the aforementioned and traditional skepticism towards transactional profit based methods seems to have been overcome, mostly on the ground of pragmatic concerns. Even though the 2009 OECD Transfer Pricing Guidelines clarify that transactional profit method may not be applied by default on the sole ground of the circumstance that data for adopting a transaction based method may be difficult to obtain $^{58}$, it is recognized that, in some cases transactional profit methods may be more appropriate than transaction based methods ${ }^{59}$.

\section{F. Procedural issues}

\section{TRANSFER PRICING AND BURDEN OF PROOF}

Tax compliance practices vary from Country to Country depending on the respective administrative procedures and domestic legislation. A clear example is the issue of the transfer pricing documentation taxpayers are expected to provide to the tax administration in case a transfer pricing audit is conducted.

The probating importance attributed to transfer pricing documentation varies considerably from jurisdiction to jurisdiction; for instance, in the United States, the providing of contemporaneous documentation (i.e., documentation prepared ex ante) allows the taxpayer under tax audit to avoid being subject to penalties, while other Countries have not developed a consistent set of provisions concerning the probating relevance of transfer pricing documentation.

In order to overcome such differences, the OECD has devoted a specific section of its Transfer Pricing Guidelines to the issue of documentation. This endeavor for harmonization is also mirrored at a regional level by the efforts carried out by the EU Joint Transfer Pricing Forum $^{60}$ in the drafting of a "Code of Conduct of Transfer Pricing Documentation for Associated Enterprises in the EU",61 in 2006.

While, with respect to the issue of documentation a general consensus has been reached, at least at an EU level, significant differences, often directly linked to the specificities of national

\footnotetext{
${ }^{58}$ See Para. 2.4 of the 2009 OECD Transfer Pricing Guidelines.

${ }^{59}$ One of such cases may for instance be where, considering the functional analysis of the controlled transaction under review and an evaluation of the comparable uncontrolled transactions, it is found that a net profit margin analysis is more reliable than a gross margin analysis.

${ }^{60}$ The EU Joint Transfer Pricing Forum is a Group of EU Experts endorsed and established by the European Commission in 2002. Members are drawn form the academia, business councils and tax administrations operating on a consensus basis whose task is to set forth non legislative proposals in the field of transfer pricing. Even though works are carried out in an EU perspective, the approaches adopted are expressly consistent with the Guidelines provided by the OECD.

${ }^{61}$ Code of Conduct of Transfer Pricing Documentation for Associated Enterprises in the EU, in OJC176 of $28^{\text {th }}$ July 2006, 1
} 
jurisdictions, exist in the realm of how the burden of proof shall be allocated in transfer pricing disputes. In broad terms, in transfer pricing audits, the ex post application of one of the transfer pricing methods in order to ascertain the arm's length nature of a given transaction implies that the Tax Administration can rely on a presumption which is up to the taxpayer to controvert. In this respect, the burden of proof in transfer pricing matters is typically shifted on the taxpayer. At the same time, non rebuttable presumptions are typically not admitted.

Due to the inherently bilateral nature of transfer pricing, most problems actually arise from the interaction between different jurisdictions. Even though transfer pricing is a fairly globalised matter in its conceptual architecture ${ }^{62}$, there is no homogeneity in the way different States actually determine the arm's length nature of a given transaction and quantitatively determine the arm's length prices or profit margins.

Along with the difficulties deriving from the clash of different practical approaches to the matter, further problems arise from the fact that the ideal term of comparison of any transfer pricing audit, that is, prices or profit margins emerging from the arm's length negotiations between actors operating in perfectly functioning markets is something that is rarely encountered in the real world.

Beyond the formal aspects concerning the attribution of the burden of proof, flexibility should be endorsed also due to the circumstance that the proof in transfer pricing cannot be merely factual based but, rather, it implies a rational process centered on the correct understanding and application of principles that, in the definitive, rely on economic theories. In this respect, the elements of a correct understanding of the economic conceptual tools underlying to all transfer pricing regulations and methodologies, paired with a bona fide behavior from both actors against a share background of reasonability should be emphasized more at the expense of a formalistic approach to the attribution of the burden of proof ${ }^{63}$.

As a pragmatic remedy to the uncertainty that characterizes the application of the arm's length principle, the OECD, as well as, to various extents, national legislations set forth the proposal to adopt, in specific circumstances, an approach based on "safe harbors", that is, on " a simple set of rules under which transfer prices would be automatically accepted by the national tax administration" ${ }^{\prime 64}$.

Safe harbors may be provided under different forms, however they can be referred to two main categories:

- $\quad$ safe harbors implying the exclusion of certain transactions (e.g., those whose size is below a certain threshold) from the scope of application of transfer pricing legislation;

- $\quad$ safe harbors implying the application of simplified transfer pricing rules (e.g., the individuation of ranges within which prices or profits shall fall in order to be presumed being compliant with the arm's length principle).

\footnotetext{
${ }^{62}$ J. CALDERON, 'The OECD Transfer Pricing Guidelines as a Source of Tax Law: Is Globalization Reaching the Tax Law?', (2007) 1 Intertax, 4.

${ }^{63}$ In this sense, see C. GARBARINO, Manuale di tassazione internazionale, II Edition, Milano, 2008, 1209.

${ }^{64}$ See Para. 4.95 of the 1996 OECD Transfer Pricing Guidelines.
} 


\section{AdVAnCE Pricing AgReEMents}

Advance Pricing Agreements (hereinafter, A.P.A.s) represent the most striking innovation in the field of transfer pricing. As with the vast majority of transfer pricing conceptual tools and administrative solutions, A.P.A.s originate in the United States and have subsequently been endorsed by the $\mathrm{OECD}^{65}$, then making their way in a number of jurisdictions.

A.P.A.s, as the very name suggests, consist in a pre-emptive negotiation between taxpayers and one or more Tax Authorities and have the effect to minimize possible litigation costs for both parties.

In this respect, the A.P.A. appears as a complex procedure finalized to reaching of " $a$ n arrangement that determines, in advance, of controlled transactions, an appropriate set of criteria for the determination of the transfer pricing of those transactions over a fixed period of time" ${ }^{\mathrm{s}}$.

A.P.A.s basically serve the function to integrate judicial and administrative instruments unilaterally foreseen by each domestic legislation by providing a platform suitable to anticipate the resolution of possible arising disputes. In this respect, A.P.A.s qualify as precious instruments that safeguard legal certainty and the expectations of M.N.E.s with respect to their tax planning strategies. A.P.A.s have then the merit of having introduced, at least in theory, an element of stabilization into an often unpredictable domain such as transfer pricing, as the arm's length principle is often as much a vague concept as it is essential.

Due to transfer pricing being a cross-border phenomenon, A.P.A.s can be unilateral, bilateral or multilateral; i.e., they can involve one, two or more tax administrations. The very OECD Guidelines on this matter are not enthusiastic about unilateral A.P.A.s as they are apparently not suitable to avoid possible cases of international double taxation, since the State having tax jurisdiction over the other counterpart to the transaction could disregard the terms set forth by the unilateral A.P.A. and put adjustments into place.

The A.P.A. is a tax payer driven process, as it is foreseen that the taxpayer shall start proposing an agreement; preliminary meetings then ensure the possibility to evaluate the actual pros and cons of the agreement.

On the other hand, the taxpayer is faced with specific responsibilities and duties: it is expected that the payer justifies the methods and the economic indicators of choice and that it adopts critical assumptions concerning the economic and operational scenarios that will occur at the time when transactions covered by the A.P.A. will actually take place.

The basic elements that are constitutive of an A.P.A. are:

- the perimeter of the transactions included in the scope of application of the A.P.A.;

- the methodology to be adopted in order to assess the transactions covered by the A.P.A.;

\footnotetext{
${ }^{65}$ In this respect, an Appendix concerning how an A.P.A. should be implemented has been included in the OECD Transfer Pricing Guidelines.

${ }^{66}$ OECD Transfer Pricing Guidelines, Annex 3, Para. 3.
} 
- the selection of comparable transactions functional to the assessment of the transactions covered by the A.P.A.

A.P.As are typically pro tempore agreements, whose extension is generally comprised between three and five years. In this respect, A.P.A.s, due to their limited temporal horizon have the advantage that they can be fine tuned on a regular basis.

At an EU level, remarkable endeavors have been devoted by the EU Joint Transfer Pricing Forum in providing specific guidelines for the handling of A.P.A.s involving Tax Administrations of the Member States which have culminated in the setting forth of a Communication by the European Commission (COM(2007) 71 of $26^{\text {th }}$ February 2007). The Communication does not cover only A.P.A.s but other forms of cooperation between Tax Administrations, such as simultaneous tax examinations on the assessment side and mediation and prior consultation procedures in the domain of the prevention of disputes.

\section{SECTION 2: EXCESSIVE PRICING}

\section{A. INTRODUCTORY REMARKS}

Excessive pricing is a broad concept that may refer to a variety of abuses of dominant position, under competition law: it may be the result of an integrated company's plan to "squeeze out" its downstream competitor; it may be a strategy for an incumbent to "get around" a statutory duty to deal; or it may be, more simply, the constitutive element or the "flip-side" of price discrimination or bundling.

At its most basic, however, excessive pricing may also constitute an abuse in and of itself to the extent that it can be identified as a prohibited "exploitative" conduct. The term "exploitative" is used as opposed to "exclusionary" to refer to situations where the dominant company exploits the other market participants without altering the structure of the market. Yet an important remark is that not all jurisdictions have enacted prohibitions against exploitative abuses: these prohibitions are rather a peculiarity of the European Union and some other legal regimes (amongst others, many European Countries). By contrast, the United States in their longstanding antitrust history have always abstained from addressing exploitative conducts through competition law, letting price control aside as an exclusively regulatory matter. Perhaps one could infer from this respective feature of the antitrust regime that an important transatlantic divide exists over the degree to which a government is entitled to intervene in the market, in particular when it comes to challenging the pricing policy of a dominant firm in a non-regulated market. Such conclusion, however, might also be too quickly drawn: in fact, the practice shows that excessive pricing precedents at Community level have been rather limited both in number and in scope, tending to be focused on exclusionary rather than exploitative conduct. Nonetheless, the existence of such divide could still be found, admittedly, at the national level, having Regulation 1/2003 left open the possibility for Member States to establish stricter regimes 
with respect to the treatment of dominant firms ${ }^{67}$.

Investigating the broad range of excessive pricing regulations that are in the force at the national level would be a burdensome exercise, and is out of the scope of our inquiry. We will remain focused on excessive pricing cases decided by Community courts, more precisely limiting the inquiry to those cases where the allegation of abuse was based on exploitative -rather than exclusionary- conduct.

In this respect, the most famous "pure" excessive pricing cases are General Motors $^{68}$,United Brands ${ }^{69}$, British Leyland ${ }^{70}$, SACEM $^{71}$, and, most recently, Port Of Helsingborg ${ }^{72}$.

\section{B. RELEVANT CASE LAW}

\section{EARLY CASES: SETTING THE MILESTONES OF EXCESSIVE PRICING}

In General Motors the Court of Justice, the court was confronted with the question of whether the prices charged by GM for vehicles conformity inspections of its European Models were unfair, considering that they corresponded to those charged for the much more costly inspections conducted for the American models. On that occasion the court, while annulling a Commission decision finding abusive monopoly pricing, gave its first hint for discerning what an "excessive price" might be: it recognized that, in principle, an abuse could include "the imposition of a price which is excessive in relation to the economic value of the service provided". This sentence was then picked up and circumstantiated further in United Brands, where the Court gave its famous dicta that charging a high price would constitute an abuse if "[the price] has no reasonable relation to the economic value of the product supplied ${ }^{73}$."

The Court also ventured to say that this excess could, inter alia, be determined objectively if it were possible for it to be calculated by making a comparison between the selling price of the product in question and its cost of production, which would disclose the amount of

\footnotetext{
${ }^{67}$ See Art. 3.2, COUNCIL REGULATION (EC) No 1/2003 of 16 December 2002 on the implementation of the rules on competition laid down in Articles 81 and 82 of the Treaty .

${ }^{68}$ Case 26/75 General Motors v Commission [1975] ECR 136.

${ }^{69}$ United Brands $v$ Commission of the European Communities [1978] ECR 207 appeal on Commission decision OJ [1976] L95/1.

${ }^{70}$ Case 226/84 British Leyland Public Limited Company v Commission, ECR (1986) 3263.

${ }^{71}$ Cases 110/88, 241/88 and 242/88, Lucazeau and others v. SACEM and others, 110/88 [1989] ECR- 2811 at §25.

${ }^{72}$ Case COMP/A.36.568/D3, Scandlines Sverige AB v Port of Helsingborg, Commission Decision of July 23, 2004 ("Port of Helsingborg"), Para. 102. See also Case COMP/A.36.568/D3, Sundbusserne v Port of Helsingborg, Commission Decision of July 23, 2004, Para. 85.

${ }^{73}$ Case 27/76, United Brands Company v Commission [1978] ECR 207, Para. 250.
} 
the profit margin. This, however, was indicated as only one possible way to determine the reasonableness of a price, by no means intended to be exhaustive. Therefore, it concluded crafting a two-pronged test applicable to any possible scenario to establish an excessive pricing abuse: "The questions therefore to be determined are whether the difference between the costs actually incurred and the price actually charged is excessive, and, if the answer to this question is in the affirmative, whether a price has been imposed which is either unfair in itself or when compared to competing products." 74

In the aftermath of United Brands, commentators split on the issue of whether the two limbs of the test were to be considered alternative or cumulative. An influential stream of scholarship ${ }^{75}$ supported the former view, maintaining that the direct cost calculation (i.e. the first limb of the test) should enjoy priority. They referred to various decisions, including in particular one of the Court of Justice concerning the royalties charged by the Societè des Auteurs, Compositeurs at Editeurs de Musique ("SACEM", a copyright collecting society), where the Court admitted that "a price-cost comparison would be impossible, given the nature of the product -the creation and protection of a musical piece ${ }^{\text {,76 }}$. This seemed indeed just a natural consequence of the fact that innovation is essentially a risky and uncertain process, and the definition of a "normal" ratio between investment and innovation cannot be given ex ante. But they also found some support in the judgment of the ECJ in Bodson ${ }^{77}$, where the comparative market test was relied upon in isolation as a possible method to determine whether a price was excessive $^{78}$.

Nevertheless, despite the apparently convincing nature of the evidence presented above, the prevailing scholarship has supported the opposite view that the test should be two-fold ${ }^{79}$. Their standard argument, which implies that a mere calculation of price-cost margins cannot be satisfactory, is that that such calculation is a meaningless exercise for the purposes of Article 82(a), unless:

- it is assumed that any price exceeding cost be abusive; or

- there is a 'workable' competitive benchmark ${ }^{80}$.

This view is now confirmed by the Commission decision in Port of Helsingborg, which settled the debate in favour of a cumulative test ${ }^{81}$.

${ }^{74}$ United Brands, supra note 73, Para. 252.

${ }^{75}$ See for example E PIJNACKER HORDIJK, 'Excessive Pricing Under EC Competition Law: An Update in the Light of 'Dutch Developments", in B. HAWK (Ed.), Fordham International Antitrust Law and Policy, New York, 2002, 469 .

${ }^{76}$ M. GAL, 'Monopoly Pricing as an Antitrust Offence in the U.S. and the EC: Two System of Belief About Monopoly?', (2004) 49 Antitrust Bulletin, 33.

${ }^{77}$ Case 30/87, Corinne Bodson v SA Pompes funèbres des régions libérées [1988] ECR 2507.

${ }^{78}$ See E PIJNACKER HORDIJK, supra note 75, 469.

79 See, by way of example, C ESTEVA-MOSSO, S.RYAN, 'Article 82-Abuse of a Dominant Position', in J. FAULL, A. NIKPAY (Eds.), The EC Law of Competition, Oxford, 1999, 192.

${ }^{80}$ See R. O' DONOUGHE, J. PADILLA, The Law and Economics of Art. 82, Oxford, 2006, 611.

${ }^{81}$ Case COMP/A.36.568/D3, Scandlines Sverige AB v Port of Helsingborg, Commission Decision of July 23, 2004, Paras. 147, 149. See also Case COMP/A.36.568/D3, Sundbusserne v Port of Helsingborg, Para. 85. 
But let's analyse more closely what the economic foundations were to support a finding against a pure (or prevalent) price-cost comparison approach. Essentially, this approach is equivalent to the "Cost Plus" method that we have seen in the context of transfer pricing. Both can be exposed, therefore, to the following criticism.

The most crucial issue is, as pointed above, that there is no predetermined appropriate measure of costs against which the actual costs are to be benchmarked. Even admitting that, according to conventional economic theory, prices should be equal to marginal costs of production, there is no commonly agreed method to define what factors determine how production costs should be allocated, both over time and across different product lines.

Some economists have advocated the use of a proxy, precisely to avoid the intricacies and complications associated with a product-by-product cost allocation exercise: the long-run average incremental cost (hereinafter, L.R.A.I.C.) calculated from total value of the costs that are needed to enter a market and begin supplying a product, as an average over total output ${ }^{82}$. The facilitation of this proxy is that under L.R.A.I.C., the computation of common costs is excluded: only the costs that are causally related to the activity at issue are taken into account. The L.R.A.I.C. is thus equal to the long-run average avoidable cost of production (hereinafter, L.R.A.A.C. ${ }^{83}$, plus the sunk costs incurred upon entry.

As there is no consensus on what is the most appropriate reference between a precise computation of all costs and the use of the aforementioned proxy, this appears as an insurmountable obstacle for the use of price-cost comparison as a sole criterion to define excessiveness. Like the Court of Justice recognised in United Brands, "there may at times be very great difficulties in working out production costs which may sometimes include a discretionary apportionment of indirect costs and general expenditure and which may vary significantly according to the size of the undertaking, its object, the complex nature of its set up, its territorial area of operations, whether it manufactures one or several products, the number of its subsidiaries and their relationship with each other." ${ }^{84}$

In fact, there is at least some consensus to the view that the pricing policy of a multiproduct firm should be analysed in its entirety and not in a piecemeal fashion, product by product. Unfortunately, however, the consensus regarding this issue is not unanimous: recent evidence for that is the fact that the "portfolio pricing" argument was ultimately rejected by the United Kingdom Competition Appeals Tribunal (hereinafter, C.A.T.) in its famous Napp decision ${ }^{85}$.

The fact that there seems to be a prevailing view amongst different economic theories is

\footnotetext{
82 See R. O' DONOUGHE, J. PADILLA, supra note 80, 614.

83 As explained by O'Donoughe and Padilla, supra note 80, 615: "The LRA.A.C. is the total value of costs that are avoided in the long run if a company stops supplying a particular product, as an average over total company output. If L.R.A.A.C. exceeds current market prices, it would be cheaper and more rational for a firm to shut down the relevant product line than to continue in business".

${ }^{84}$ Case 27/76, United Brands Company v Commission [1978] ECR 207, Para. 254.

${ }^{85}$ Case CA98/2/2001, Napp Pharmaceuticals Holdings Ltd and Subsidiaries, Decision of Director General of Fair Trading on March 30, 2001 ("Napp"), on appeal Napp Pharmaceutical Holdings Limited and Subsidiaries v Director General of Fair Trading [2002] CompAR 13.
} 
not sufficient, in itself, to make of it a sound basis for policy-making on such a sensitive issue as pricing regulation, which touches upon the central nerve of a free-market economy. Arguably, an economic theory must yield a sufficient, almost incontestable recognition in the field before it can be a erected as a blueprint for how the law should stand.

A second significant obstacle to the implementation of a price-cost criterion lies in the process of constructing a reasonable final price from the (already far less than crystal-clear) cost figures: any definition of what constitutes a reasonable profit margin must take into account a whole range of factors, including, e.g., economies of scale, sunk costs, and risk.

This is an aspect directly related to the issue of the appropriate measure of costs introduced above, and will therefore not be further investigated in this context. Suffices to bear in mind that even where an appropriate measure of costs could be identified, a second part of the test would have to be satisfied by looking at whether the margin between prices and cost is unreasonable. As mentioned above and further discussed in the following section of this paper, some solution to this problem has been attempted in proposing the optimal rule for predatory pricing, by recurring to the use of L.R.A.I.C. as a proxy and relying on a presumption of legality as a complement to it. One may wonder, then, why has this type of solution not been applied to the realm of excessive pricing, which poses the same problem of avoiding "undue" interference with the mechanism of prices.

\section{TOWARDS A GREATER RELIANCE ON “COMPARABLES”: THE “BRITISH LEYLAND” AND "SACEM” DECISIONS}

Another important decision case was British Leyland, where the Commission for the first time engaged in comparative market testing: given that the market where the abusive pricing had allegedly occurred was that for left-hand driven cars, and that vendors did not have to incur for their sale on that market any meaningful additional cost than in the market of right-hand driven cars, the latter market served as a useful parameter of comparison. The Commission also looked at the evolution of prices over time, thus making also an inter-temporal comparison, and spotted a sharp rise denoting a discriminatory intent on the pricing policy of the car sellers. As a result, the Court of the market investigation, the Commission found it unreasonable that importers of left-hand-driven cars had to pay six times the amount paid by right-hand-driven cars, and characterized this as an excessive pricing abuse.

After few years, the concept of comparative market testing was expanded to include the use of geographic market comparison: in $S A C E M$, the Court was asked to deliver a preliminary ruling on whether the fact that a French Copyright collecting society was charging more for licenses of performing rights than were similar collecting societies located in other Member States might constitute an abuse of dominant position under article 82 of the Treaty. The Court answered in the affirmative, explaining that: "When an undertaking holding a dominant position imposes scales of fees for its services which are appreciably higher than those charged in other member states and where a comparison of the fee levels has been made on a consistent basis, that difference must be regarded as indicative of an abuse of dominant position (Emphasis added). In such a case it is for the undertaking in question to justify the difference in reference to 
objective dissimilarities between the situation in the member state concerned and the situation prevailing in all the other member states." ${ }^{\prime 6}$

It is important to note that this ruling places great emphasis on the role of comparatives: where the dominant firm is found to be charging a rate that is substantially higher than that charged in comparable firms acting in comparable markets, it will be upon her the burden to demonstrate that this is justified by legitimate reasons. This seems to reverse the order of the conditions laid down in the United Brands ruling, which is why some commentators invoked this judgments in support of their reading of the alternative nature of such conditions.

After a closer look, however, one can infer that the Court simply created a second and different rule with regard to excessive prices, perhaps to ease the task of the Commission were this convinced to prosecute such prices as an abuse, it could either:

- benchmark price-cost margins, in which case it would then have to look also for a confirmation through valid comparators; or,

- find a valid comparator, in which case it would then be upon the dominant firm to bring up cost-price margins and other relevant factors to justify the divergence vis à vis its comparator(s).

Another interesting aspect of the judgment is that the Court established that, were the Competition authority to follow this alternative and facilitated method to determine "excessive prices", it would be irrelevant whether the dominant firm has just covered its or extracted just a reasonable profit out of the capital invested. Differently from what could be gathered from previous case-law, indeed, low profits are not evidence of permitted behavior as much as high price-cost margin are not decisive evidence of abusive behavior: the crucial determination is whether the actual price in the market is higher than that charged by the comparators.

\section{ONE STEP FURTHER - OR, PERHAPS, BACK? PORT OF HELSINGBORG AND THE ENHANCED IMPORTANCE OF ECONOMIC ANALYSIS}

The most recent and in a sense revolutionary judgement on excessive pricing was probably delivered in the Port of Helsingborg case, dealing with a port fee for ferry operators that was alleged to be excessively high. The Commission here, after clarifying that the United Brands test is necessarily two-pronged and thus that a price-cost evaluation would have to be followed by a look for comparables, undertook a rigorous analysis of all the distinctive features of the port market and eventually found out that the characteristics of such market were so peculiar that it was not possible for it to find any valid comparator. In order to reach that finding, and as a consequence reject the complainant's allegations, the Commission the notion of "economic value" and it aligned it more closely aligned with basic economic principles, recognizing that "the economic value of the product/service cannot simply be determined by adding to the approximate costs incurred in the provision of this product/service... a profit margin which would be a pre-determined percentage of the product costs. [Rather, the] economic value must be determined with regards to the particular circumstances of the case and take into account

\footnotetext{
${ }^{86}$ Cases 110/88, 241/88 and 242/88, Lucazeau and others v. SACEM and others, 110/88 [1989] ECR- 2811 at Para.
} 25. 
also non-cost factors such as the demand for the product/service." 87

This part of the decision was particularly welcomed by leading economists like Padilla and Donoughe ${ }^{88}$, precisely because it finally places on the demand side the consideration it deserves. But other points of the decision were quite illuminating as well, contributing to a clarification of the concepts of "costs" and "reasonable margins" used in the decision practice and at the number of factors that are considered when defining their magnitude. These clarifications are:

- the need to recoup investments (such as high sunk costs) and the intangible value of the good should be included in an assessment of the "economic value." This was reflected by the regard had for the particular nature of the port due to its ability of being tailored to customer's needs within that area, and the additional value that it would gain for that simple reason, even though that value was not reflected in its annual accounts ${ }^{89}$.

- the need to take into account also any opportunity-cost for that good ${ }^{90}$, i.e. any loss from potential uses to which the assets in question could be assigned.

Perhaps an economist could argue, to simplify, that these clarifications are nothing but a specification of the enhanced consideration for demand-side contingencies, in the first case, and a necessary adaptation to the "more economic approach" developed by the Commission, as to the second.

For non-economists, however, the novelty and the scope of these clarifications are probably much more striking and important, for they make excessive pricing cases even more complex than they used to be, and extremely difficult to win for plaintiffs.

\section{ECONOMIC ANALYSIS VS. “BRIGHT-LINE” RULES: WHAT'S THE BEST WAY FORWARD?}

While the case-law has demonstrated appreciating the difficulties and dangers associated with the crucial tasks of overseeing prices, they seem to have come to a closer alignment with economic theories, abandoning the formalism that originally characterized excessive pricing cases and embracing that "more economic approach" that is now pervading the enforcement of competition law as a whole.

Nevertheless, the courts have not eliminated the reference to certain formal yardsticks, such as the use of geographical and inter-temporal comparison, amongst others, which have maintained a residual role of guidance in the competitive assessment conducted by the competition authorities. But was the departure from such formal, bright-line rules desirable? What seems remarkable is

\footnotetext{
${ }^{87}$ Port of Helsingborg, Para. 227.

${ }^{88}$ See R.O' DONOUGHE, J. PADILLA, supra note 80, 612.

${ }^{89}$ Port of Helsingborg, Para. 209.

${ }^{90}$ Ibid.
} 
that while in British Leyland the court had basically established a shortcut to make the rules on excessive pricing more amenable both to enforcement and predictability by the dominant firm, in Port of Helsingborg the shortcut was undone by bringing in punctilious economic meaning to the term "comparator" which makes it, concretely, very difficult for it to be found. One may then validly raise the argument that, given the great importance of the reference to comparators and particularly of the predictability thereof, the Court should have restrained the extent and depth of economic analysis to be used in excessive pricing cases.

A couple of more specific questions can be added to the aforementioned one: do the magnitude and frequency of the error costs justify such departure from formalistic decisionmaking? And if so, are these costs so high as to warrant reverting to in depth economic analysis? As stressed above, the case-law has been unclear in this regard, swinging back and forth from full reliance on economic analysis. Some valuable indications to trace the lost way, then, may be found in the rules applied in the context of predatory pricing.

\section{SECTION 3: PREDATORY PRICING}

\section{A. PREDATORY PRICING: TRADITIONAL VS. MODERN DEFINITIONS}

A predatory price is a price that is profit-maximizing only because of its exclusionary or other anticompetitive effects, i.e., a price implying the sacrifice of profits in the short run in order to eliminate competition and get higher profits in the long run.

As recently explained in a working paper on the economic theory of predation ${ }^{91}$, this is only the modern definition of predation, which is much more general than the one traditionally employed by antitrust economics until the rise of the "Chicago revolution" " of antitrust law. Even though the legal definition of predation as such has not been amended in response to the Chicago critique, Chicago scholars had in fact a significant indirect impact on the design of the modern rule. More explicitly, their meditations opened the door to the consideration in predatory pricing cases of a variety of theories and speculations that was previously not necessary to address, essentially because the conceptual framework underlying predation was much more simple and uncontroversial. The insurgence of these theories thus increasingly complicated the courts' task to take in due time a final decision which accounts for all the equities on both the plaintiff's and the defendant's side, owing to the greater risk of falling into one of those "type I errors" (i.e., false positives) that are jointly feared by the Chicagoans and their counterparts ${ }^{92}$.

\footnotetext{
${ }^{91}$ See N. GIOCOLI, When Low is no Good: Predatory Pricing and the History of Antitrust Economics (Part I), 2009, available at SSRN: http://ssrn.com/abstract $=1412808$, giving a complete and extensive overview of the evolution of the legal standard for predatory pricing in the US.

${ }^{92}$ As clearly put by a recent piece of scholarship on the influence of the Chicago School on antitrust law, "The Harvard School's sensitivity to the possibility of deterring pro-competitive conduct as a result of judicial error is largely related to the Chicago School's error cost framework. The powerful intellectual foundations of the errorcost framework, grounded in basic decision theory and accepted by Chicago, Harvard, and most economists, is one
} 
This prompted courts to seek new ad hoc rules precisely to avoid all the intricacies which going down the Chicago-route would imply.

The more traditional definition of predation, according to which a dominant firm sells its products below cost in order to eliminate rivals and subsequently earn a monopoly profit, was focused on the two key elements of market power and intent, meaning by the latter the intention to exploit a price reduction in order to increase or consolidate that power. Since a rigorous reading of such a combination would make it extremely difficult to bring a successful case of predatory pricing, the American courts ${ }^{93}$ relaxed the requisites essentially alleviating plaintiffs from the need to substantiate a proof of the existence of either one of these requisites with sufficient precision: all a plaintiff needed to show was a convincing story from which the court could infer the existence of dominance and of the intent to exclude competitors through predation. The most frequently told story, and one which the courts seemed satisfied with, was that of "long pursue" or "deep pockets", according to which the predator could take advantage of superior financial resources (usually deriving from the presence in multiple markets) to remain on business while driving the prey out of the market.

With regard to intent, instead, which in theory would require proving that there is no rational explanation to justify the company's behaviour other than excluding competitors out of the market, the courts began to infer its existence from the likelihood of verification of the effects, i.e. of a successful predation. And due to the "structure-conduct-performance" paradigm that dominated antitrust economics from the 1930s to the 1970s, this information was normally inferred from the structural data itself, i.e. the existence of market power. Essentially, then, the standard applied to predatory pricing resulted as one of a "per se" rule: if a company was found to have sufficient market power and to fall within one of the stories considered plausible to support a predatory pricing allegation, it would have no way to escape liability.

\section{B. THE FIRST ATTACK TO THE TRADITIONAL MODEL AND THE PROPOSED ALTERNATIVES}

The breakthrough occurred when the "Chicago-boy" Mc Gee first pointed at the fact that the theory that was normally relied upon by the courts was in fact a flawed one ${ }^{94}$. In line with the school's emphasis on efficiencies and with the assumption of functioning markets, Mc Gee suggested that predating is never rational (i.e. profitable) since there are always more profitable

reason why the framework has become a building block for modern competition policy". See J. D. WRIGHT, 'Overshot the Mark? A Simple Explanation of the Chicago School's Influence on Antitrust', (2009) Competition Policy International, Forthcoming, 16; George Mason Law \& Economics Research Paper No. 09-23. Available at SSRN: http://ssrn.com/abstract=1370641.

${ }^{93}$ This historic part of the analysis of predatory prices is by nature focused on US antitrust law, as no European counterpart existed until the creation of the European Community in 1957.

94 J.S. MC GEE, 'Predatory Price Cutting: the Standard Oil (N.J.) Case', (1958) 1 Journal of Law and Economics, 169. 
strategies available to the firm ${ }^{95}$; and that as a result, predatory attempt should be considered at best very rare. And even then, there is a list of possible countermeasures that could be deployed to prevent the occurrence of predation, such as the possibility for customers to stock up during the low-price period, or for the prey to offer long-term contracts to its customers warranting them the provision of the good at the competitive price or for financial investors to back the prey's resistance ${ }^{96}$.

The essential recommendation by McGee concerning the legal standard, then, was that the plaintiff's burden could not be satisfied simply by arguing a plausible "deep pocket" story, rather it was necessary for it to show with convincing evidence that the market was affected by serious barriers to entry able to impede the necessary competitive readjustments which would otherwise occur once the price-rising period begins.

After McGee's contribution, there have been substantially no predatory pricing cases in which the US Supreme Court has taken the opportunity to formulate a new legal standard supporting this more economic, price-theory-driven approach. What is perhaps more remarkable, in the only case that reached the Supreme Court before the mid-Eighties ${ }^{97}$ the Court rejected all the claims that focused on the importance of structural barriers -which was in itself the most important element of the test proposed by McGee. The discussion continued, however, in the economic literature: in reaction to McGee, other Chicago scholars came out some years later offering alternative stories upon which predation's rationality could be based, such as the "reputation" story (meaning that a firm may want to establish a reputation of strong predator in one market to show that it is generally hostile to entries in any other market), the "threat" story (meaning that predation is used as a signal to the new entrant that market conditions are unfavourable) and the "error of evaluation" story (meaning that a firm may overestimate its capacity to accomplish predation). Overall, the common theme of the Chicagoans was to point to the central role played by strategic considerations in the decision of engaging in predation. As remarked by Posner: "Eliminate strategic considerations and it becomes impossible to construct a rational motivation for predatory pricing without assuming (very uncongenially to a Chicagoan) asymmetric access to the capital markets for financing a period of below-cost selling. But to ignore strategic considerations is not satisfactory." ${ }^{, 8}$

A natural reaction to this enhanced confusion on the economic theory regarding predation would have been, logically, that of transforming the sort of "per se" illegality standard into a "rule of reason" analysis, meaning to a full evaluation of the circumstances of the case to see whether any particular theory of harm is warranted in the particular case. The courts, however, did not demonstrate being enthusiastic about going down this route: probably disturbed by the

\footnotetext{
${ }^{95}$ The key argument was independent from the idea that supra-competitive margins would be swept away by new entrants: he observed that since predation involves unnecessary and avoidable losses of profit, and the magnitude of these losses is normally higher for the predator than for the prey, the firm will always have more profitable strategies at its disposal (such as direct acquisition of the prey for example).

${ }^{96}$ The remark was based on the consideration that if a firm is efficient, there is no reason why it should find no assistance from capital markets.

${ }^{97}$ Utah Pie Co. v. Continental Baking Co., 18 L.Ed.2d 406; 87 S.Ct. 1326; 386 U.S. 685 (1967).

${ }^{98}$ R.A. POSNER, 'The Chicago School of Antitrust Analysis', (1979) 127 U. PA. L. Rev., 939.
} 
contradictions of economic theories, that were being exasperated by the fact that some disagreements existed even within the Chicago school, they were unwilling to dip into the much more sophisticated economic analysis that an embracement of the strategic considerations approach would require.

On the contrary, the Supreme Court found itself much more comfortable with a brightline rule, devised by the two famous Harvard scholars Philippe Areeda and Donald Turner ${ }^{99}$. The two scholars proposed a test based exclusively on costs, upon which the courts should draw their inference of legality. The test was grounded on the basic economic theory that under competitive conditions, firms set their price equal to marginal costs (hereinafter, M.C.), i.e. the increase in total expenditure resulting from a small rise in output of the relevant product ${ }^{100}$. As pricing below marginal cost entails a sacrifice of profits, this economic theory suggested that any price below reasonably-anticipated, short-run marginal costs ought to be illegal. But as marginal costs do not generally result from a firm's accounts, and are difficult to identify (especially because of the different practices of costs allocation, and the vagueness of the notion of "reasonably anticipated" costs), the test proposed the use of Average Variable Costs (i.e., the sum of average fixed costs and the sum of average variable costs: hereinafter, A.V.C.) as a proxy to determine the illegality of below- cost selling.

While the test finally offered a clear benchmark for the judicial assessment of predatory practices, it was obviously not immune from critics by a variety of economists and legal scholars. More precisely, these critics took issue with two aspects of the test. First of all, as anticipated above, the neglecting of strategic considerations: this was the biggest critique coming from a rich strand of literature that had its origin in the aftermath of McGee's article, but that had gone reinvigorating throughout the years and was at its peak when the famous Areeda-Turner publication came out.

The second critique was on the use of A.V.C. as a threshold. In particular, the main objection was that A.V.C. may differ from M.C., and may be significantly lower, which would imply that the rule would let unpunished some prices that fall in fact much below marginal costs.

Following this criticism, some commentators have proposed to base the test on Average Avoidable Costs (hereinafter, A.A.C.), instead, i.e. to calculate the difference between the incremental cost of remaining in the market and the avoidable cost that the firm's exit would imply and aim to punish the pricing conduct when this difference is positive $\mathrm{e}^{101}$. This would have the advantage of not separating variable and fixed costs, taking into account also the latter element in the computation of the appropriate cost-based comparator. But it is still imperfect, for

${ }^{99}$ P. AREEDA, D.F. TURNER, 'Predatory Pricing and Related Practices under Section 2 of the Sherman Act', (1975) 88 Harvard L. Rev., 697.

100 Note that this theory, although widely accepted and adopted by standard textbooks, is not immune from critics: see R.PITTMAN, Who Are You Calling Irrational? Marginal Costs, Variable Costs, and the Pricing Practices of Firms, Economic Analysis Group Discussion Paper 09/03, US Antitrust Division, available at http://www.usdoj.gov/atr/public/eag/discussion_papers.htm.

${ }^{101}$ See W.J. BAUMOL, 'Predation and the Logic of the Average Variable Cost Test', (1996) 39 Journal of Law \& Economics, 49 and OECD, Predatory Foreclosure (2005) DAF/COMP 14, 23. See also P BOLTON, J.F. BRODLEY, M.H. RIORDAN, 'Predatory Pricing: Strategic Theory and Legal Policy' , (2000) 88 Georgetown L. J., 2239, who advocate use of the average avoidable cost test in place of the A.V.C. test. 
it suffers from the many complications arising out of the fact that some assets can be redeployed between different businesses, that there may be a revenue spill-over effect associated with some sales and that one cannot establish with certainty the measure of costs associated with an event that has not occurred ${ }^{102}$.

Another proposal has been to rely on L.R.A.I.C., meaning the firm's total production costs (including the product), less what the firm's total cost would have been had it not produced the product, divided by the quantity of the product produced ${ }^{103}$. While this test would also avoid the complication of cataloguing costs as fixed or variable and allocating common costs, it cannot discern the situation of firms with high fixed costs that need to price at a relatively low price to "penetrate" the market. Therefore, proponents of this test argue that prices below L.R.A.I.C. are not in themselves sufficient to prove predation, and should be accompanied by circumstantial elements proving intent to exclude an equally or more efficient competitor.

There is a reputable stream of scholarship, however, warning against the use of an "intent" requirement for predation cases. Such scholarship finds perhaps its most illustrative representation in the following excerpt of an opinion delivered by Richard Posner as Appellate Judge for the $7^{\text {th }}$ Circuit ${ }^{104}$ : "the importance of intent in tort and criminal law does not automatically translate in antitrust law for the obvious reason that when an individual kills, steals from or causes a loss to another, the society as a whole undoubtedly suffers, but the opposite is true when a firm "kills" its rival by "stealing" all its customers thanks to lower prices or superior products: in such a case the society as a whole is better off because this is what is supposed to happen in competitive markets!"

In sum, the proposal by Areeda and Turner was followed by a lively discussion, not only on the appropriate notion of costs but also, more generally, on the cutting short of strategic considerations, which had in fact been showed by the literature to be an important justification for the rationality of predatory pricing. ${ }^{105}$

\section{THE LESS THAN FULl JUDiCIAL ENDORSEMENT OF THE “AREEDA - TURNER” TEST: US Vs. EU}

The result of this fight between economists has been, quite obviously, the failure of a full endorsement of the Areeda- Turner test. It is important, however, to note the different twist that such development has taken in the EU and the US.

\footnotetext{
102 See O’DONOUGHE, PADILLA, supra note 80, 243.

${ }^{103}$ See P. BOLTON, J.F. BRODLEY, M.H. RIORDAN, supra note 101, 2272.

104 In a 1986 7th Circuit decision, quoted by W.K. TOM, 'Game Theory in the Everyday Life of the Antitrust Practitioner', (1997) 5 George Mason L. Rev., 464: see Olympia Equip. Leasing Co. v. Western Union Tel. Co., 797 F.2d 370, 379 ( $7^{\text {th }}$ Cir. 1986).

105 J.F. BRODLEY, G.A. HAY, 'Predatory Pricing: Competing Economic Theories and the Evolution of Legal Standards', (1981) 66 Cornell L. Rev., 738.
} 
In the EU, antitrust legislation had been in force since almost 30 years when the ECJ came down with its leading decision on predatory pricing. In $A K Z O^{106}$, the ECJ relied on the Areeda- Turner test as a point of reference. However, it did not want to rule out the possibility that a firm may be engaged in predatory conduct even if its prices are above total costs. On the contrary, it explicitly recognized that the rule would be under-inclusive, and admitted that strategic considerations might play a role in the predator's plan.

Even admitting the importance of strategic considerations, though, the Court drew an important distinction with regard to a specific category, that is, selling below A.V.C.: in that particular case, the exclusionary consequences are so self - evident that no evidence of intention to eliminate a competitor is required. Accordingly, the decision proceeds setting a different standard for prices below average total costs (that is to say, fixed costs plus variable costs), but above average variable costs: these must be regarded as abusive only if they are determined as part of a plan for eliminating a competitor. Despite the soundness of such categorization of prices, one may question whether strategic considerations should be brought in as an additional element not only to infer the existence of predation, but also to evoke a legitimate defence.

Those elements, in fact, are implicitly downplayed by the $A K Z O$ test as they are confined to a later stage, where the court assesses whether the defendant's claims falls under one of the possible justifications for an apparently predatory behaviour. This, as will be explained below, is a consequence of the nature of the presumption, which is not a definite one ("iuris et de iure") but rather just an inference ("iuris tantum") that can be subject to rebuttal by the defendant.

Admittedly, these elements still play an important role in the dominant firm's decisionmaking, enabling it to pursue secure strategies upon a reading of a relatively well-established case-law. Yet even a quick review of these justifications indicates that their consideration is not quite a fully-fetched balancing of economic arguments, for this would impair the ability to deliver an expedite and consistent decision-making, this time by the courts and competition authorities. A good example is the so called "meeting competition" defense that has been raised and admitted, at least in principle, in a series of cases (including AKZO, Hilti ${ }^{107}$, Tetra Pack $I I^{108}$ , BPB Industries ${ }^{109}$, British Sugar/Napier Brown ${ }^{110}$ Irish Sugar ${ }^{111}$, Digital ${ }^{12}$ and Wanadoo ${ }^{113}$ )

${ }^{106}$ Case C -6 2/86 Akzo Chemie BV v. Commission [1991] ECR 1-3359.

${ }^{107}$ Eurofix-Bauco v Hilti, OJ 1988 L 65/19. Hilti was obliged to cease all price discrimination by ensuring that any differences in its prices were justified by differences in costs, except where it was necessary to meet a competitive offer, in making promotions, or where to do so would generate sales that Hilti would not otherwise make.

${ }^{108}$ Tetra Pak II, OJ 1992 L 72/1, Para. 148 (argument that Tetra Pak was merely meeting competition recognized but rejected on factual grounds).

${ }^{109}$ See BPB Industries plc, OJ 1989 L 10/50, Para. 133, where the Commission accepted BPB's "Super Schedule A" prices because they were neither predatory nor part of any scheme of systematic alignment.

${ }^{110}$ See Napier Brown/British Sugar, OJ 1988 L 284/41, Para. 31, where the Commission suggested that while undercutting a competitor's prices would be abusive, matching them would not.

${ }^{111}$ See Irish Sugar plc, OJ 1997 L 258/1, Para 134 ("[T] here is no doubt that a firm in a dominant position is entitled to defend that position by competing with other firms on its market.").

${ }^{112}$ In this case the Commission recognised that dominant companies must be allowed to offer prices reductions (called "Allowances") in individual cases "to meet comparable service offerings of a competitor. No Allowance shall 
but surprisingly (or perhaps wisely, considering the complex calculation it may involve) rejected in its Guidance paper on enforcement priorities ${ }^{114}$ with regard to prices below L.R.A.I.C. (since the Commission will limit its inquiry to what is necessary for the application of the "as efficient competitor test" ${ }^{115}$. Similarly, the possibility of purportedly incurring in start-up losses for penetration purposes finds a recognized but limited role, since the Commission has made clear in Wanadoo that it will strongly rely on extensive circumstantial evidence of exclusionary intent such as internal documents, probability of recoupment and actual or likely exclusionary effects (instead of entertaining the question of whether it can be reasonably anticipated that future profits will compensate the start-up losses).

It appears, therefore, that the role of economic analysis at the justification stage is restrained by the imposition of limits to the speculations that the defendant may require the courts to make. Nonetheless, the very existence of the possibility to rebut a purely cost-based analysis with a (limited) variety of economic arguments (i.e., the efficiencies identified in Section III D of the Guidance Paper) is to be appreciated, as it prevents the realization of the "worst-case" scenario of automatic application of the prohibition to conducts that may in itself be pro-competitive.

In the US, where the concern for type I errors has been historically greater, the leading decision on predatory pricing demonstrated even more openness to the defendant's arguments, establishing that to bring about a predatory pricing claim a plaintiff has to show:

- price in appropriate measure under the average variable rivals' cost;

- reasonable prospect of recouping investment ${ }^{116}$.

The most important nuance from previous case-law was that the Court introduced a requisite (prospect of recoupment) that detaches from the subjective notion of intent, marking an important steps towards a complete objectivization of the standard. Such test gives more leeway to the defendant's argument in the first place, by setting a very high evidentiary threshold (which has resulted, in fact, in no successful predation case since the decision has been rendered up until at least $1998^{117}$ ).

be offered until Digital has completed an internal review process designed to verify that the proposed Allowance is offered in good faith as a proportional response to real or (based upon information from the customer or other reliable sources) reasonably anticipated competitive offerings and will not result in a foreclosure or distortion of competition for the servicing of Digital Systems in any Member State."

${ }^{113}$ See Case COMP/38.233, Wanadoo Interactive, Commission Decision of July 16, 2003, OJ C 262, 23.10.2004, 53, Para. 316.

${ }^{114}$ Communication from the Commission C(2009) 864, Guidance on the Commission's enforcement priorities in applying Article 82 of the EC Treaty to abusive exclusionary conduct by dominant undertakings (hereinafter, "Guidance Paper")

115 Which takes into account as legitimate defenses only the role of efficiencies, and provided they fulfill the conditions for objective justifications set out in Section III D of the Guidance Paper. See ibid., at. 67.

${ }^{116}$ Brooke Group Ltd. v. Brown \& Williamson Tobacco Corp., 509 U.S. 209, 220 (1993).

117 See A. EDLIN, 'Stopping Above-Cost Predatory Pricing', (2002) 111Yale L..J., 941 ("Since 1993, when the Supreme Court decided Brooke Group Ltd. v. Brown \& Williamson Tobacco Corp., no predatory pricing plaintiff has prevailed in a final determination in the federal courts."). While one scholar stated that there have been more 
More provocatively, one could argue that under the American rules the defendant's arguments of prospective efficiency, meeting competition, launch of promotional offers and so forth are already accounted for "by default" through the incorporation of the recoupment requisite. And while one may argue that its existence is a consequence of the different approach of anti-monopoly law in the US - where a firm can be accused of monopolization or attempt to monopolize even in the absence of the structural element of market dominance, which is, in turn, a prerequisite for Art. 82 claims under EC competition law - this fails to recognize that there is a subtle difference between the ex ante dominance required in EC law and the ex post dominance $^{118}$ (or oligopolistic concentration, as established by the Brooke Group decision) that would be necessary to infer a reasonable prospect of recoupment under the US rule. Even though it seems reasonably correct to assume that if a firm is capable of behaving "to an appreciable extent independently from its competitors" ${ }^{119}$ it will not lack the ability to raise prices without triggering further entries, this paradigm may not hold true in rapidly evolving markets, where barriers may not last long enough to allow the necessary recoupment, or where potential competitors whose business is still in its infancy might quickly grow to represent a competitive threat.

Secondly, another key novelty of the decision was the explicit admission, for the first time $^{120}$, that a cost-based standard would drive assessments in predation cases. This, however, was the part of the test that made it more uncertain, since the Court did not pin down any specific reference of a reasonable "measure of costs" to be used as a benchmark Allegedly, such an open definition was designed to embark on the useful cost-based test recommended by Areeda and Turner, yet at the same time avoiding an ex ante condemnation of potential pro-competitive conduct. Significative evidence to corroborate this argument is the fact that the Court refused to grant certi orari on two occasions when the question of determining the "appropriate measure of costs" was squarely presented $^{121}$.

recent victories, the cases cited do not support the proposition that predatory pricing has been conclusively shown. In this sense, see D. A. CRANE, 'The Paradox of Predatory Pricing', (2005) 91Cornell L. Rev., 4.

${ }^{118}$ See Matushita Electric Industrial Co v Zenith Radio 475 U.S. 574 (1986), at 588-89:"For the investment to be rational, the [predator] must have a reasonable expectation of recovering, in the form of later monopoly profits, more than the losses suffered".

${ }^{119}$ Standard definition of dominance, used for the first time in Case 27/76 United Brands Company and United Brands Continental v Commission [1978] ECR 207, Para. 65, and picked up by the majority of Art. 82 decisions, as well as by the Guidance paper (Para. III, 10).

120 Even though in previous decisions the Court referred to the use of cost-based method as a potential criteria, it had not established this as a necessary for the competitive assessment. See Matushita Electric Industrial Co $v$ Zenith Radio 475 U.S. 574 (1986) and Cargill Inc v Monfort of Colorado, Inc 479 U.S. 104 (1986). See also Utah Pie Co. v. Continental Baking Co., 386 US 685 (1967), at 702-703: the Court held that each of the three defendants had violated the Robinson-Patman Act by selling below cost and engaging in other predatory behavior. However, it did not hold, nor even suggest, that below-cost pricing was critical to a violation. See ibid. ("It might be argued that the respondents' conduct displayed only fierce competitive instincts. Actual intent to injure another competitor does not, however, fall into that category, and neither, when viewed in the context of the Robinson - Patman Act, do persistent sales below cost and radical price cuts themselves discriminatory.").

${ }^{121}$ See Rebeil Oil Co., INc. v Atl. Richfield Co., 146F.3d 1088 (9th Cir 1998), cert. denied , 25 US 1017 (1998); Int'l Travel Arrangers v. NWA, 991 F.2d 1389 (8th Cir. 1993), cert. denied, 510 US 932 (1993). 
Overall, then, it seems that the Court decided to go very careful about regulating predation. This approach stems from the belief (reinforced by some of the above mentioned writings by the Chicago school) that predation is uncommon, and therefore judicial mistakes that would condemn pro-competitive price-cutting are more dangerous than regulatory pitfalls which leave unpunished potentially anticompetitive conduct. Notably, the Court stressed that : "Mistaken inferences [in predation cases] are especially costly, because they chill the very conduct [vigorous price-competition] that antitrust laws are designed to protect" $" 122$.

Naturally, because of such a one-sided resolution of the trade-off between type I and type II errors, the rule exposed itself to the criticism of being too permissive: it created, in fact, a "safe harbor" for above-cost selling which may leave some effective predation strategy unpunished ${ }^{123}$. The result is therefore an opposite one with respect to the "worse case-scenario" depicted above for the EU legislation, with the only (important) circumstantiation that such scenario has not materialized in that context, having the case-law recognized the existence of some possible "objective justifications". In the US, conversely, the Supreme Court has not admitted this exception, nor it has established whether any circumstantial evidence is apt to rebut the presumption of legality enjoyed by above-cost selling.

Whether this is desirable depends, once again, on the importance attached to the values of administrability and predictability. Just as a rule of per se illegality may be justified on the basis of "economic prediction, judicial convenience and business certainty" ${ }^{124}$, so does a rule of per se legality. The ultimate question, however, is whether the danger of letting a potentially anticompetitive category of aggressive price-cutting (i.e., above-cost selling) unpunished is outweighed by the societal gain derived from saving the costs related to the identification, the enforcement and litigation of the practices that fall under such category.

\section{A MORE EQUITABLE AND ADMINISTRABLE TEST: TAKE-HOME LESSON?}

In the writers' perspective, the rule developed in the EU is preferable to that designed by the US Supreme Court on two grounds: first, that it defines a precise and predictable measure of costs. This allows a dominant firm to rationally decide its pricing policy, without incurring risk

\footnotetext{
122 see Matushita v Zenith, 475 US 574, 591 (1986); at 594, quoted in Brooke Group, at 226.

${ }^{123}$ See J. B. KIRKWOOD, 'Controlling Above-Cost Predation: An Alternative to Weyerhaeuser and Brooke Group', (2009) Antitrust Bulletin; Forthcoming. Available at SSRN: http://ssrn.com/abstract=1027261; P. BOLTON, J.F. BRODLEY, M.H. RIORDAN, 'Predatory Pricing: Response to Critique and Further Elaboration', (2001) 89 Georgetown L. J., 2516 at note 114. See also J.BAKER, 'Predatory Pricing after Brooke Group: An Economic Perspective', (1994) 62 Antitrust L.J., 591; J. P. GUILTINAN, G. T. GUNDLACH, 'Aggressive and Predatory Pricing: A Framework for Analysis', (1996) $60 \mathrm{~J}$. Marketing, 94; L. A. SULLIVAN, W. S. GRIMES, The Law of Antitrust: An Integrated Handbook, II Edition, New York, 2006, 168. Finally, Professors Edlin and Elhauge concur: A. S. EDLIN, 'Stopping Above-Cost Predatory Pricing', (2002) 111 Yale L. J., 944 and E. ELHAUGE, 'Why Above-Cost Price Cuts to Drive Out Entrants Are Not Predatory - and the Implications for Defining Costs and Market Power', (2003) 112 Yale L. J., 686.

${ }^{124}$ See Arizona v. Maricopa County Medical Soc'y, 457 U.S. 332, 354 (1982).
} 
of being disrupted in its operations by doubtful predation claims and having to rebut the alleged theories of harm by recurring to ad hoc economic experts' testimony.

Second, it properly allocates the burden of proof by requiring the defendant- and not the plaintiff or the competition authority- to provide internal documents proving its costs and pricerelated policies: these are elements that would otherwise be extremely difficult to prove, given the sensitiveness and confidentiality of the documents and the general reluctance of a company to give an accurate quote of its actual costs and internal policies.

The presumptive nature of the rule, in fact, reaps the benefit of serving as a roadmap to hard and fast decision making, without at the same time being an obstacle to the introduction of a justification story on the part of the defendant. It does not preclude, thus, the use of more sophisticated economic theories, as long as they are tried and proved by the defendant.

\section{CONCLUSIONS}

The way tax law and antitrust law deal with the intervention of the public authority into the most intimate dimension of a business, that is, its pricing policy are different in scope, depth and, quite obviously, purpose.

First of all, transfer pricing is primarily concerned with cross-border situations, while excessive pricing and predatory pricing monitoring are predominantly a domestic issue, even though their legal source may be grounded in supranational provisions, as it is the case with EU legislation on the subject.

Secondly, transfer pricing is a system for monitoring physiological situations, as it is just logical that in a world were taxes can affect rates of return, M.N.E.s factor in also tax rates when defining their cross-border pricing policies. On the contrary, both excessive pricing and predatory pricing are pathological phenomena whose occurrence is by definition limited as not all the firms operating in a given market can afford to put such behaviors into practice.

Thirdly, while transfer pricing can encompass some "win - win" situations for taxpayers and Tax Administrations alike, e.g., when a satisfactory A.P.A. is reached, the antitrust monitoring of company pricing is always a zero sum game: since the safeguard of the markets is a public policy issue per se, there is a very limited scope for bargaining between antitrust authorities and firms.

At the same time, however, the way tax authorities and competition authorities deal with the monitoring of prices, costs and profit margins, which may be subject to manipulation by firms, inevitably share some features.

The first resemblance is that the monitoring exercise, in both the areas of transfer pricing and excessive pricing/predatory pricing, is conceptually based on a benchmarking assessment. In the case of transfer pricing, the benchmark is represented by the arm's length standard; in the case of predatory pricing and excessive pricing, such benchmark is to be found in the notions of A.V.C. and "valid comparator", respectively.

In both cases, the foremost conceptual difficulty encountered by policy makers is how to 
turn principles and standards which are often based on complex and abstract economic concepts into a workable diagnostic tool with which real actors such as firms (and not markets!) come into dealing.

With respect to transfer pricing, an almost century long development in the United States and a decade long debate at the OECD level have led to a more consolidated platform of concrete applicable methodologies.

Despite their conceptual and practical shortcomings, both transaction-based methods and profit-based methods developed within the context of transfer pricing are well experimented tools which can be applied with a satisfactory degree of consistency and predictability. In this respect, the very existence of a lively debate forum such as the OECD has contributed to an accurate weighing of the different methods and to the building of a consolidated theoretical and operational platform.

On the contrary, the diagnostics of excessive pricing and predatory pricing has mostly developed through national or regional case law, often characterized by a limited deference to the principle of stare decisis, as it is often common in matters that undergo a rapid evolution and have yet to find their ubi consistam.

In this respect, a preliminary observation confirms the importance of soft law and discussion forum on the shaping of sensitive economic law policy making in a world so globalised such as ours. Competition law, at least in the specific areas that are under the focus of this study, would then greatly benefit from the creation of ad hoc commissions composed of representatives from multinational enterprises, national administrations and scholars, in a way akin to the valuable experience of the EU Joint Transfer Pricing Forum.

Take, for example, the problem of finding a comparable: determining whether a price or a profit level indicator is such to fall outside the scope of an arm's length range or whether a pricing practice constitutes a form of excessive or predatory pricing implies, in any case, a comparative analysis between the transactions or the prices under scrutiny and a term of reference. On this particular issue, the OECD Transfer Pricing Guidelines devote a whole section, discussing the variables that should be taken into account depending on the transfer pricing methodologies that have been adopted, as well as the adjustments to be applied in order to restore comparability ${ }^{125}$.

On the contrary, the developments in the evaluation of "fair prices" for excessive pricing purposes have taken different and inconsistent paths throughout the case law, and lack a proper unitary coordination. This has led to a remarkable state of uncertainty for firms, which, for the time being, cannot confidently predict the terms of comparability against which they will be judged.

Another crucial contact point shared between antitrust and international taxation is the challenging task of devising the appropriate legal test to identify "unfair prices". On that respect, we have seen in the preceding paragraphs how the three distinct price regulations have ended up approaching the concept of "fair" prices in a completely different fashion.

Such a circumstance may seem even more striking considering that two of these

\footnotetext{
${ }^{125}$ Such a structured approach has been confirmed and brought forward by the 2009 version of the OECD Transfer Pricing Guidelines, where a whole chapter devoted to the procedural and timing issues of a comparability analysis have been introduced.
} 
regulations pertain to the same area of law, and actually relate to the same article ${ }^{126}$. But this internal inconsistency can be explained, at least in part, with an argument similar to that made above to remind the separate realms in which antitrust and taxation operate: such differentiation is required by the distinct object of inquiry that these two regulations are concerned with. While excessive pricing, in fact, requires to prove that the prices charged are beyond any rational expectation from the consumers' perspective, the prohibition against predatory pricing only applies if the rationality of the prospective predation is proven to the requisite legal standard.

The analysis is thus remarkably different in its subjective scope, as the authority in the latter case it will be to a lesser extent able to draw inferences from the market, having instead to recur to the analysis of internal documents of the suspected predator to verify its pricing policy. This seems to justify a more limited role, in this context, for economic analysis: the fact that some information can be provided only by the defendant recommends, for administrative convenience and simplification purposes, to adopt a different settings, by which the intention to accomplish predation is presumed as long as circumstances in the market point in that direction ${ }^{127}$.

Despite the persistent differences between the two fields, a valid argument can be made as the present work purports to do - that some limits to the use of economic analysis must be imposed in the context of excessive pricing, too, precisely in order to avoid the costs and complexity that an adequate weighing of all relevant circumstances in that case may involve. This would be, after all, in line with the fact that the case-law on excessive pricing still relies to a great extent on the use of comparables as presumptions that facilitate the assessment.

Yet, the use of such facilitators has not been streamlined in such a way that they can be considered as rebuttable presumptions; rather, they represent a legal hurdle that allows for the authority to conclusively qualify a price as excessive. Unfortunately, a clarification on whether a defendant would be entitled to raise any defense for some predetermined objective justifications (such as, for instance, the need to recoup start-up losses or the matching of prices charged by certain competitors) is yet to be made.

To that extent, it seems that the type of structure used within predatory pricing may serve as a valid source of inspiration. But the test would have to be substantially different, so as to accommodate the different object of inquiry: the undertaking accused of excessive pricing would have to come out with data collected from consumers, for example through market surveys, to prove that its product is in fact perceived as different and superior to those offered by competitors or used as a comparator.

The very fact that we evoke the recourse to the same "structure" of the presumption used for predatory pricing is a symptom, in itself, of the importance that administrative simplification plays in the enforcement of antitrust policy.

Yet, this is hardly something peculiar to this area of the law: like many other context in which the law is not able to capture ex ante through a detailed picture if a particular conduct falls in the box of legality or illegality, so international taxation needs to refer to some guidelines for

\footnotetext{
${ }^{126}$ Art. 82 EC Treaty.

${ }^{127}$ A presumption which, as seen above, can be rebutted by the defendant providing additional evidence to that effect.
} 
administrative simplification purposes. As a result, the need to simplify -sometimes even brutally simplifying- complex economic concepts to be performed in order to make them working regulation, assessment and decision tools is another issue common to both antitrust and international taxation.

In the realm of transfer pricing, a patent example is the very notion of "arm's length dealing". This definition may be appear as a self explaining and empirical one, that is, that entities belonging to the same multinational group should carry out transactions between themselves as if they were independent enterprises. However such a "counter-factual" approach implies an in-depth understanding of how competitive markets work and seem to incorporate a bias according to which we have to assume that markets out there operate in a perfectly competitive fashion.

Moreover, speaking about arm's length transactions would seem slightly out of scope: namely, properties that apply to markets cannot be applied sic et simpliciter to transactions: a competitive market is an aggregation of many transactions whose consolidated outcome satisfies some given economic properties, however there is no reason to assume that the overall properties applying to a whole market shall be directly detected in isolated transactions.

Such a reflection leads us to another key issue where it seems that competition law has something to teach to tax law, or at least to the way the OECD has been constantly interpreting transfer pricing issues: setting the focus on single transactions. Instead of focusing on a transaction-based approach, when dealing when competition law driven price analysis, both the American and European Courts have been consistently adopting an enlarged perspective based on aggregated variables. So, for example, all of the cases discussed above in the context of excessive pricing arose out of a series of transactions where an allegedly excessive price was charged. Even though in theory an individual transaction would be sufficient to trigger the application of the rule, the practice shows that this has never occurred. And in the case of predatory pricing, it is even more unlikely that a single transaction with artificially low price gives rise to competitive concern for the basic reason that, even in case of markets characterized by large and powerful buyers, firms do not base their sales plans on one single transaction and thus the predator would not be able to drive competitors out of the market in absence of a series of such transactions.

A similar sort of simplifying approach developed within the context of transfer pricing, even though with some degree of caution and suspicion, is the envisaging of "safe harbors", a system which allows firms featuring given subjective requisites to handle uncertainty, which, both in transfer pricing and in competition law-driven price monitoring, is an extremely critical issue for firms.

A further area of inquiry where comparisons between tax law driven transfer pricing assessment and competition law driven excessive pricing/predatory pricing assessments can be profitably set forth with respect to the question whether the relationship between public authorities and firms can be rendered more co-operative and set in a general scenario of mutual understanding based on shared bona fide.

In the realm of international taxation, the answer would seem to be a resounding yes: at least in theory, the whole concept of A.P.A., possibly the major transfer pricing innovation in recent years, is based on such a conceptual platform. Nonetheless, when it comes to practice, it appears that only a handful of Countries has implemented bilateral or multilateral A.P.A.s, often 
with great difficulty and without achieving the expected deflating effects on the mass of transfer pricing based litigation cases that keep tax courts worldwide busy.

Within the context of competition law, a system akin to A.P.A.s would seem to appear less workable, as, at least in theory, the safeguard of a healthy functioning of the markets is perceived as a non negotiable matter. In practice, however, this distinction does not hold entirely true since competition authorities do in fact retain some discretion as to the scope and prioritization of their enforcement actions. As a result, the introduction of a co-operative procedure for the determination of "fair prices" that more closely resembles A.P.A. cannot be $a$ priori excluded. The provision of settlement procedures ${ }^{128}$ both in the US and in the EU and the successful results witnessed following the introduction of leniency programs into nearly every competition law regime are positive sign in that direction.

The issues of certainty and of the Public Authority - private firms relationships are directly linked to the procedural matter referring to how the burden of proof is allocated. In this respect, it would seem that the approaches adopted by international tax law and by competition law differ to a remarkable extent.

Namely, in the context of transfer pricing, proofs are rarely factual based but, rather, are the result of an inductive reasoning centered on the most logical and most accurate interpretation and application of the transfer pricing guidelines of reference.

On the contrary, when examining excessive pricing or predatory pricing cases, it seems that the factual element is preponderant and this exacerbates the asymmetry already resulting from the circumstance that the burden of proof with regard to the most critical issues (i.e., objective justifications and miscellaneous defenses) typically lies on the firms. Such a different notion of "proof" seems again to be rooted in the circumstance that transfer pricing can benefit from a set of almost generally universally accepted guidelines, very analytical in their structure. On the contrary, parties dealing with excessive pricing or predatory pricing matters cannot really rely on any such piece of guidance, due to the fact that soft law has not been adequately developing in this area of competition law.

Here we come the conclusion of our interdisciplinary work. The issues we have raised here represent a list that is far from exhaustive, but may serve to stimulate some reflection in the two cognate communities of tax law and competition law scholars, practitioners and officials. As it clearly appears, there is major room for cross-pollination between these two fields.

${ }^{128}$ Within an EU context, rectius, “commitments”, see Art. 9 of Regulation 1/2003. 